Mineral Surveys by the Geological Survey and the Bureau of Mines of

Bureau of Land Management Wilderness Study Areas

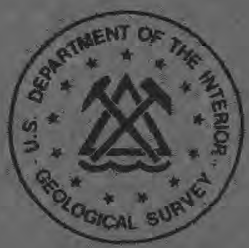

GEOLOGICAL SURVEY CIRCULAR 901
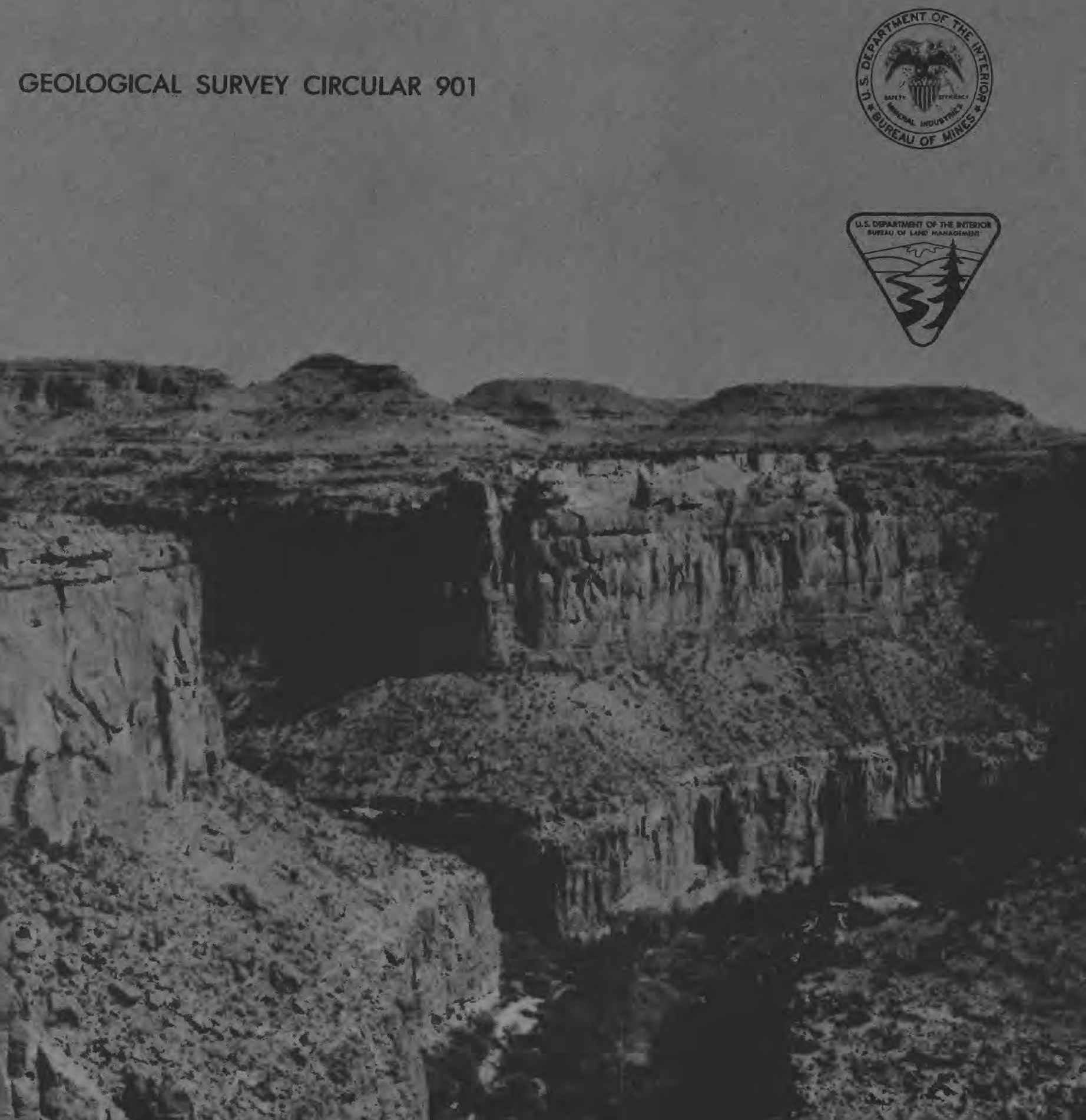
COVER PHOTOGRAPH: ARAVAIPA CANYON PRIMITIVE AREA, PINAL AND GRAHAM COUNTIES, ARIZONA. 
MINERAL SURVEYS BY THE GEOLOGICAL SURVEY AND THE BUREAU OF MINES OF BUREAU OF LAND MANAGEMENT WILDERNESS STUDY AREAS 


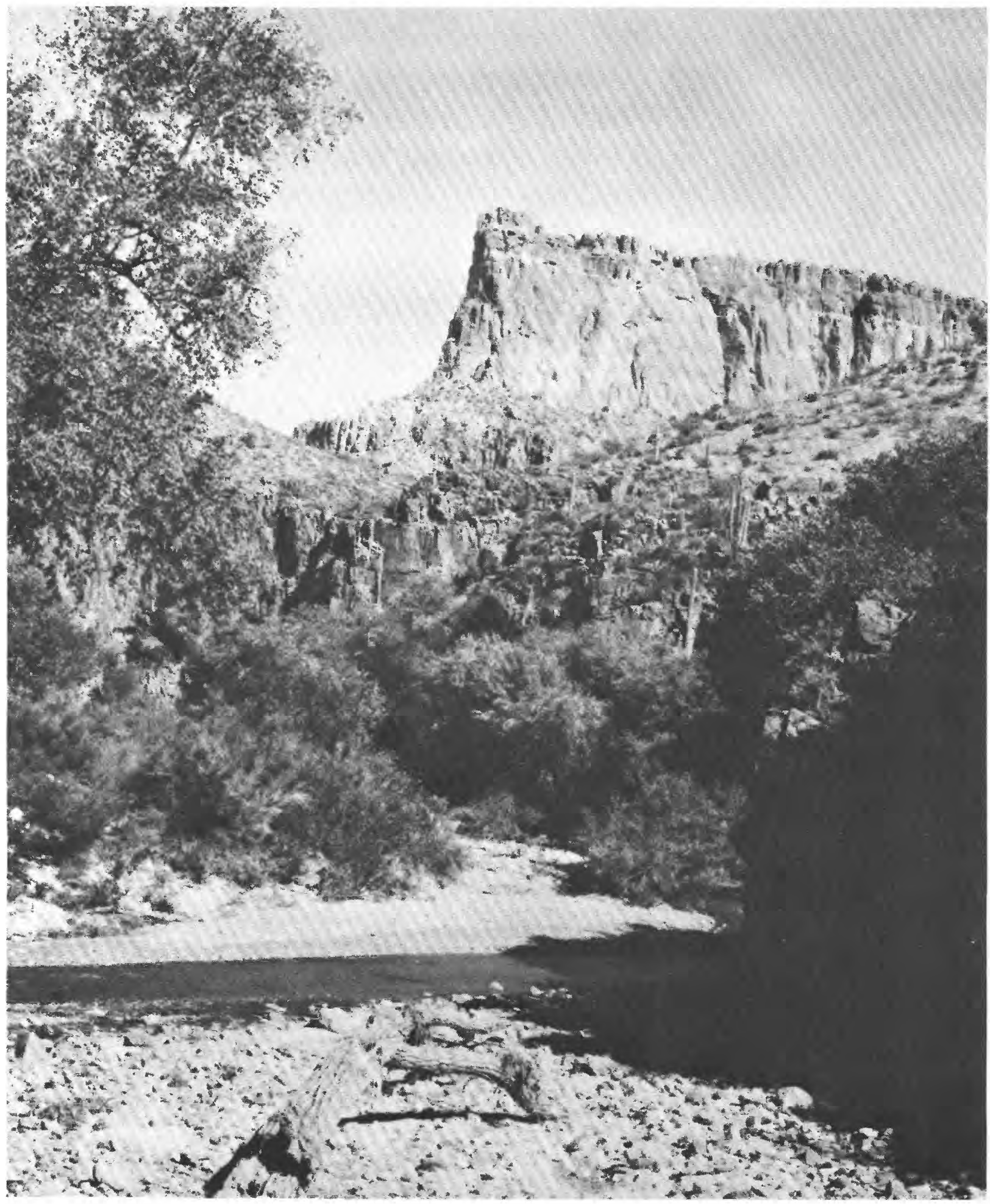

Aravaipa Canyon Primitive Area, Pinal and Graham Counties, Arizona. It was the first BLM-managed area, an Instant Study Area, to be recommended to Congress by the President for inclusion in the National Wilderness Preservation System. The area comprises a sequence of Precambrian rocks containing no known mineral deposits overlain by Tertiary volcanic rocks (shown here) locally containing zeolites. (Photograph by Medora H. Krieger, U.S. Geological Survey.) 


\section{Mineral Surveys by the Geological Survey and the Bureau of Mines of Bureau of Land Management Wilderness Study Areas}

By Helen M. Beikman, Margaret E. Hinkle, Twila Frieders, Susan M. Marcus and James R. Edward

GEOLOGICAL SURVEY CIRCULAR 901 


\section{United States Department of the Interior}

WILLIAM P. CLARK, Secretary

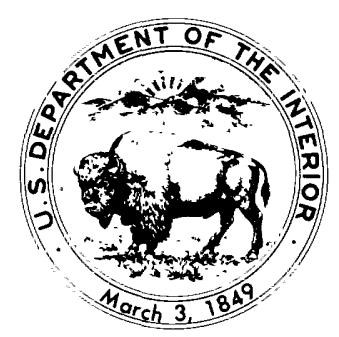

\section{Geological Survey}

Dallas L. Peck, Director

Library of Congress Catalog-card No. 83-600572

First printing 1983

Second printing 1984

Free on application to Distribution Branch, Text Products Section, U. S. Geological Survey, 604 South Pickett Street, Alexandria, VA 22304 


\section{CONTENTS}

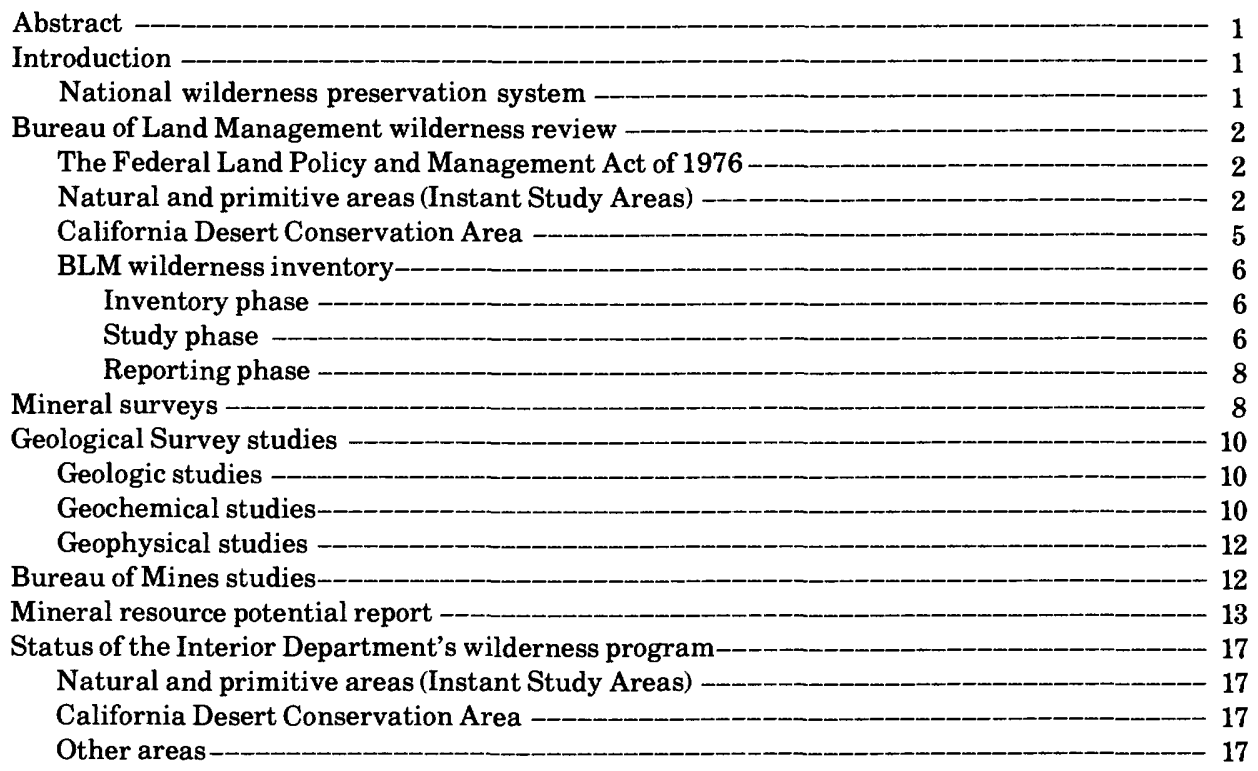

Appendix A. Memorandum of understanding (MOU) between the U.S. Geological Survey, the Bureau of Mines, and the Bureau of Land Management for mineral surveys of wilderness study areas

Appendix B. Attachment to MOU -_____ 25

\section{ILLUSTRATIONS}

Frontispiece. Aravaipa Canyon Primitive Area, Pinal and Graham Counties, Arizona

FIGURE 1. Map showing natural and primitive areas (Instant Study Areas) and accompanying table showing status of BLM wilderness review -.........................

2. Map showing wilderness study areas in the California Desert Conservation Area and accompanying schedule for completion of mineral resource potential re-

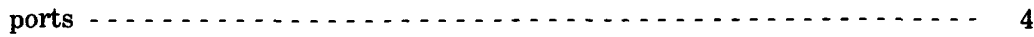

3. Diagram showing inventory phases of BLM wilderness review $\ldots \ldots \ldots$

4. Diagram of BLM study phase and reporting phase $\ldots \ldots \ldots \ldots \ldots \ldots$

5. Diagrammatic geologic, geochemical, geophysical, mines and prospects maps, and

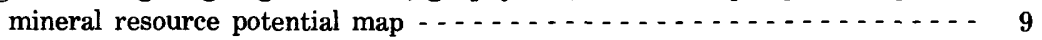

6. Geologic map shown at different scales $\ldots \ldots \ldots \ldots \ldots 11$

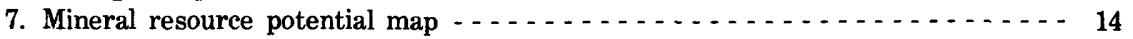

8. Diagram showing steps involved and time required for joint mineral surveys - - 15

9. Diagram showing status of mineral surveys as of May $1983 \ldots \ldots \ldots$

10. Map showing wilderness study areas outside the California Desert Conservation Area and accompanying schedule for completion of mineral resource potential

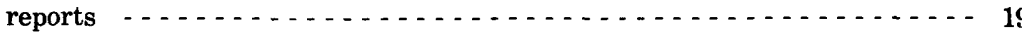


TABLE

Page

TABLE 1. Schedule for completion of mineral surveys of remaining acreage of BLM wilderness study areas recommended as suitable _- 17

vi 


\title{
Mineral Surveys by the Geological Survey and the Bureau of Mines of Bureau of Land Management Wilderness Study Areas
}

\author{
By Helen M. Beikman', Margaret E. Hinkle', Twila Frieders², \\ Susan M. Marcus ${ }^{3}$, and James R. Edward ${ }^{3}$
}

\begin{abstract}
The Federal Land Policy and Management Act of 1976 instructed the Bureau of Land Management (BLM) to review all public lands under its jurisdiction and to determine their suitability or nonsuitability for wilderness designation. As part of this process, the Geological Survey and the Bureau of Mines conduct mineral surveys of areas for which a preliminary determination of wilderness suitability has been made. The BLM has completed its wilderness inventory phase and has found that 23.2 million acres deserve further study for wilderness consideration. These 23.2 million acres of wilderness study areas include 1 million acres of natural and primitive areas (Instant Study Areas), 5.7 million acres in the California Desert Conservation Area, and 16.5 million acres in other wilderness study areas. Mineral surveys on all areas recommended for wilderness will be completed by 1990 .
\end{abstract}

\section{INTRODUCTION}

This report describes the Interior Department's wilderness program, with particular emphasis on the joint mineral surveys conducted by the U.S. Geological Survey (USGS) and U.S. Bureau of Mines, of those public lands recommended by the Bureau of Land Management (BLM) as suitable for inclusion in the National Wilderness Preservation System.

Mineral surveys by the Geological Survey and the Bureau of Mines were originally mandated by the Wilderness Act of 1964 (Public Law 88-577), which, together with subsequent legislation, dealt with national forests managed by the U.S. Forest Service of the Department of Agriculture and with certain lands managed by the Department of Interior including wildlife refuges. The Federal Land Policy and Management Act of

'U.S. Geological Survey

${ }^{2}$ U.S. Bureau of Mines.

${ }^{3}$ U.S. Bureau of Land Management.
1976 (Public Law 94-579), informally referred to as FLPMA, in turn instructed the Bureau of Land Management to review all public lands under its jurisdiction and determine their suitability or nonsuitability for wilderness designation. Areas recommended as suitable for wilderness designation by the BLM are also required to have mineral surveys conducted by the Geological Survey and the Bureau of Mines.

Although the program is not yet completed, the Geological Survey and the Bureau of Mines have conducted mineral surveys of 44 million acres of national forest and other lands in the 19 years since passage of the Wilderness Act. Individual mineral resource potential reports on hundreds of areas already have been published. In addition, a summary volume containing about 330 brief reports on the mineral resource potential of the areas studied as part of the Forest Service wilderness program will be published in 1984 .

Mineral surveys of BLM wilderness study areas are not undertaken until the final stages of the BLM wilderness review. Consequently, this program is just barely underway, and thus far mineral assessments have been completed for about 2 million acres. About 6.5 million acres remain to be surveyed.

\section{NATIONAL WILDERNESS PRESERVATION SYSTEM}

The Wilderness Act of 1964 established a "National Wilderness Preservation System for the permanent good of the whole people, and for other purposes." The Wilderness System consists of federally owned lands preserved and protected in their natural condition so that present and future generations can have the benefits of an enduring 
resource of wilderness. Only Congress can designate Federal lands as part of the Wilderness System.

Section 2(c) of the 1964 Wilderness Act defines wilderness as follows:

\begin{abstract}
"A wilderness, in contrast with those areas where man and his own works dominate the landscape, is hereby recognized as an area where the earth and its community of life are untrammeled by man, where man himself is a visitor who does not remain. An area of wilderness is further defined to mean in this Act an area of undeveloped Federal land retaining its primeval character and influence, without permanent improvements or human habitation, which is protected and managed so as to preserve its natural conditions and which (1) generally appears to have been affected primarily by the forces of nature, with the imprint of man's work substantially unnoticeable; (2) has outstanding opportunities for solitude or a primitive and unconfined type of recreation; (3) has at least five thousand acres of land or is of sufficient size as to make practicable its preservation and use in an unimpaired condition; and (4) may also contain ecological, geological or other features of scientific, educational, scenic, or historical value."
\end{abstract}

\section{BUREAU OF LAND MANAGEMENT WILDERNESS REVIEW}

\section{THE FEDERAL LAND POLICY AND MANAOEMENT ACT OF 1976}

The Federal Land Policy and Management Act instructs the Bureau of Land Management on how it is to manage the $\mathbf{4 7 0}$ million acres of land under its jurisdiction and sets forth provisions for wilderness review in section 603. In summary, section 603 directs the Secretary of the Interior and the BLM (1) to review all roadless public land areas of 5,000 acres or more and roadless islands having wilderness characteristics as defined by section 2(c) of the 1964 Wilderness Act; (2) to determine their suitability or nonsuitability for wilderness designation; (3) to have the Geological Survey and Bureau of Mines conduct mineral surveys of areas preliminarily recommended as suitable for inclusion in the National Wilderness Preservation System to determine mineral values that may be present; and (4) to report wilderness recommendations to the President no later than October 21, 1991. The President must report his final recommendations to Congress no later than 2 years after the 1991 deadline, and Congress will decide if an area is to become wilderness. The BLM is presently studying 23.1 million acres for wilderness under section 603 of FLPMA and 0.1 million acres under section 202 as described below.
Section 603(a) of FLPMA, which describes mineral surveys, is as follows:

"Sec. 603.(a) Within fifteen years after the date of approval of this Act, the Secretary shall review those roadless areas of five thousand acres or more and roadless islands of the public lands, identified during the inventory required by section 201(a) of this Act as having wilderness characteristics described in the Wilderness Act of September 3, 1964 (78 Stat. 890; 16 U.S.C. 1131 et seq.) and shall from time to time report to the President his recommendation as to the suitability or nonsuitability of each such area or island for preservation as wilderness: Provided, That prior to any recommendations for the designation of an area as wilderness the Secretary shall cause mineral surveys to be conducted by the Geological Survey and the Bureau of Mines to determine the mineral values, if any, that may be present in such areas: Provided further, That the Secretary shall report to the President by July 1,1980 , his recommendations on those areas which the Secretary has prior to November 1, 1975, formally identified as natural or primitive areas. The review required by this subsection shall be conducted in accordance with the procedure specified in section 3(d) of the Wilderness Act."

In addition to the 23.1 million acres being studied for wilderness under Section 603 of FLPMA, the BLM is also considering another approximately 150,000 acres (0.1 million) under Section 202 of FLPMA-the BLM's general planning authority. Most of these study areas are smaller than 5,000 acres and are contiguous to existing or proposed wilderness areas. Mineral surveys will also be conducted for those Section 202 wilderness study areas which are preliminarily recommended as suitable for wilderness designation.

\section{NATURAL OR PRIMITIVE AREAS (INSTANT STUDY AREAS)}

Natural or primitive areas have been specifically designated as such by the BLM and are protected under special management regulations. As described in Section 603(a) of FLPMA, wilderness recommendations on the 55 existing natural and primitive areas were to be made to the President by July 1,1980 . These natural and primitive areas were called Instant Study Areas (ISA's). Their study and evaluation became one of BLM's highest priorities, and it was necessary to start mineral surveys of certain ISA's soon after passage of the 1976 Act. At BLM's request, the Geological Survey and the Bureau of Mines began studies in 1978 on 23 ISA's, 10 of which were subsequently recommended for wilderness (fig. 1). Another 10 are deferred-study ISA's whose suitability/nonsuitability recommendations will be 


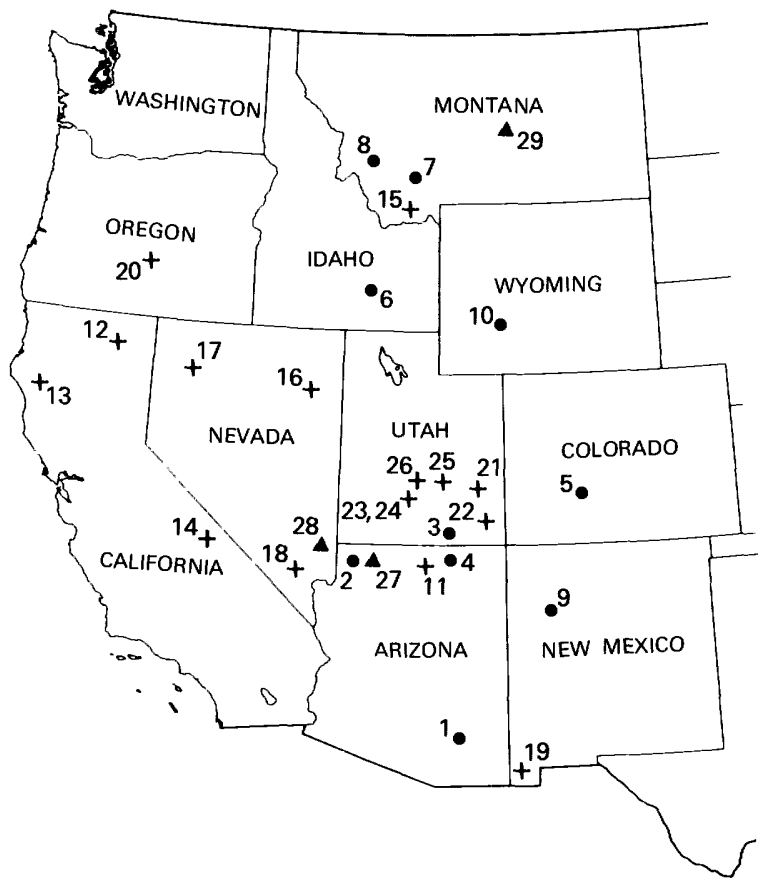

Figure 1.-Locations of natural and primitive areas (ISA's) (above) and status of BLM wilderness review (below).

Status of BLM wilderness review of natural and primitive areas

\begin{tabular}{ccc}
$\begin{array}{c}\text { Map } \\
\text { No. }\end{array}$ & $\begin{array}{c}\text { Thousands } \\
\text { of } \\
\text { acres }\end{array}$ & $\begin{array}{c}\text { Geological Survey/ } \\
\text { Bureau of Mines } \\
\text { mineral resource } \\
\text { report No. }\end{array}$ \\
\hline
\end{tabular}

Recommended as suitable.

Map symbol is:

1 Aravaipa Canyon, Arizona--_ $\quad 6.7$

2 Paiute, Arizona --_-_--_- $\quad 35.0$

3 Paria, Arizona/Utah - _-_ $\quad 18.9$

4 Vermilion Cliffs, Arizona - - $\quad 50.5$

5 Powderhorn, Colorado--_- 50.1

6 Great Rift, Idaho _-___ $\quad 355.7$

7 Bear Trap Canyon, Montana --_-_-_-_- $\quad 4.0$

8 Humbug Spires, Montana

9 El Malpais, New Mexico

10 Scab Creek, Wyoming

MF 1160-D

MF $1475-D^{b}$

MF $1475-D^{b}$

MF $1483^{b}$

MF $1462-B^{b}$

$80-835^{a}$

$11.3 \quad 80-836^{a}$

$98.4 \quad 81-557^{a}$

$7.6 \quad 80-1058^{a}$
Status of BLM wilderness review of natural and primitive areas-continued

\begin{tabular}{|c|c|c|c|}
\hline $\begin{array}{c}\text { Map } \\
\text { No. }\end{array}$ & Area & $\begin{array}{c}\text { Thousands } \\
\text { of } \\
\text { acres }\end{array}$ & $\begin{array}{c}\text { Geological Survey/ } \\
\text { Bureau of Mines } \\
\text { mineral resource } \\
\text { report No. }\end{array}$ \\
\hline
\end{tabular}

Study deferred, to be completed with a multiple-use plan.

Map symbol is: +

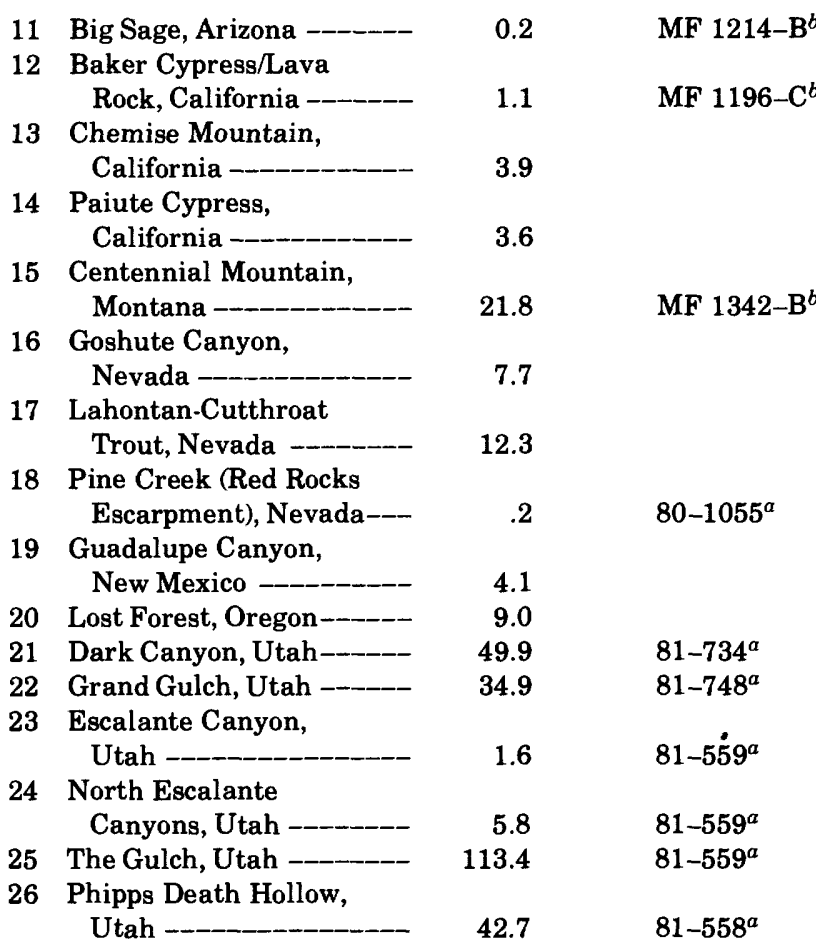

Recommended as unsuitable.

Map symbol is:

27 Turbinella-Gambel

Oak, Arizona -_-_-_-_ 0.2

MF $1146-B^{b}$

28 Virgin Mountains,

Nevada -_____ $\quad 6.6 \quad$ MF 1204-B ${ }^{b}$

29 Square Butte, Montana--- $\quad 1.9 \quad$ MLA-45-82

${ }^{a}$ U.S. Geological Survey open-file report.

${ }^{b}$ Geological Survey miscellaneous field investigations map.

${ }^{c}$ Bureau of Mines open-file report. made as part of the multiple-use plan process. Three of the ISA's on which mineral surveys were done subsequently were recommended as unsuitable. As of May 1983, the only BLM-managed area to be recommended to Congress by the President for inclusion in the National Wilderness Preservation System is the Aravaipa Canyon Primitive Area in Arizona (frontispiece). 


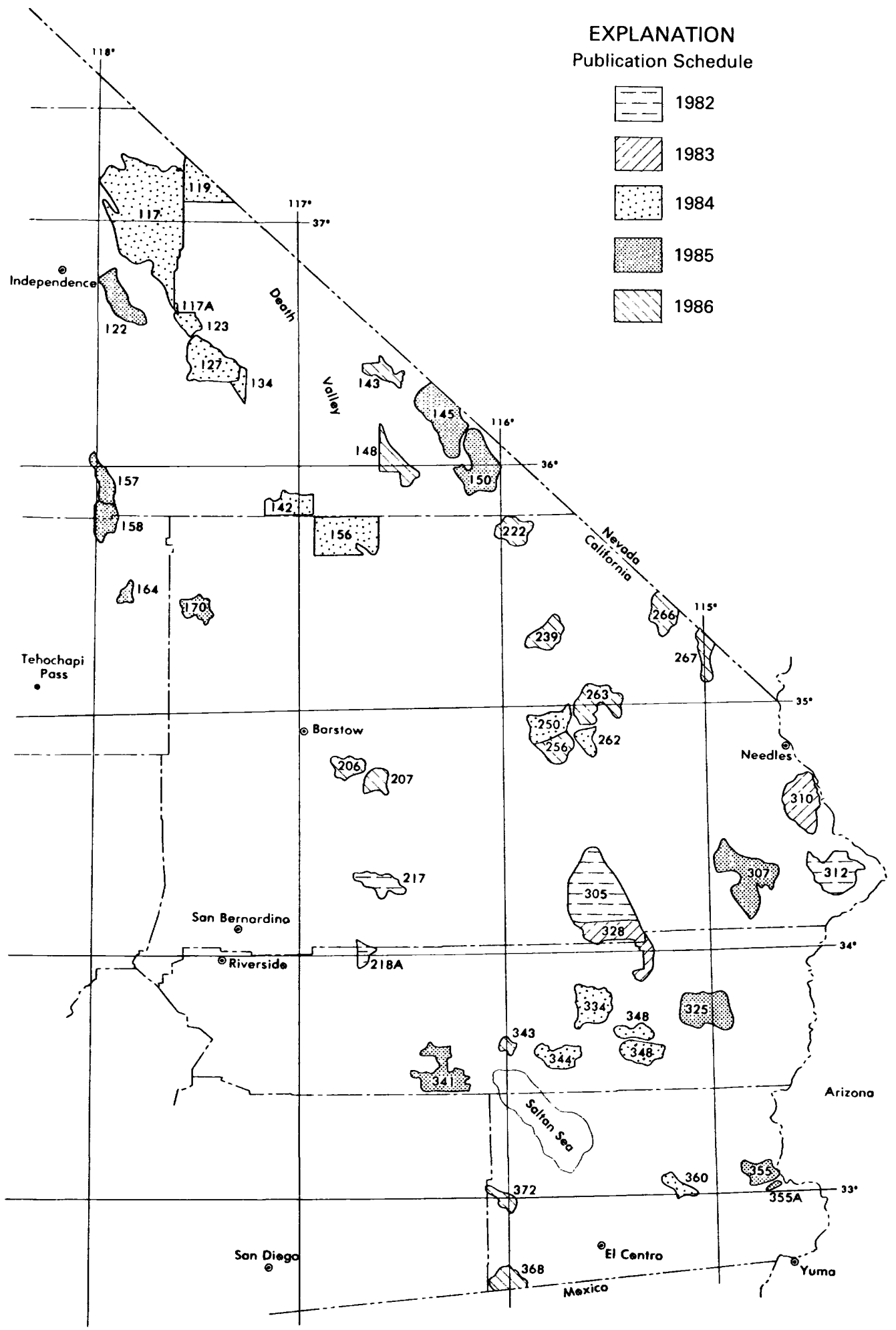

Figure 2.-Locations of wilderness study areas in the California Desert Conservation Area (above) and schedule for completion of mineral resource potential reports (right). 

potential reports

[Reports to be published by September 30 of year shown on map, facing pagel

\begin{tabular}{|c|c|c|c|c|c|}
\hline Map No. ${ }^{a}$ Wilderness study area & $\begin{array}{c}\text { Report/study } \\
\text { area }^{b} \text { in } \\
\text { thousands } \\
\text { of acres }\end{array}$ & Report No. & Wilderness study area & $\begin{array}{c}\text { Report/study } \\
\text { area }{ }^{b} \text { in } \\
\text { thousands } \\
\text { of acres }\end{array}$ & Report No. \\
\hline 1982 & & & 1985 & & \\
\hline 217 _-_Bighorn Mountains & 22.4 & MF1493-A $\mathbf{A}^{c}$ & 122 - Inyo Mountains & 62.4 & \\
\hline 218A-_-Whitewater & 11.5 & MF1478-A ${ }^{c}$ & 145 -_-Resting Spring Range & 77.8 & \\
\hline 305 -_-_Sheephole/Cadiz & 200.0 & OF $82-957^{d}$ & 150 -_-Nopah Range & 97.2 & \\
\hline \multirow[t]{2}{*}{312 -WWipple Mountains } & 85.1 & OF $82-956^{d}$ & 157 -_-_Little Lake Canyon & 30.5 & \\
\hline & & & $158----O w e n s$ Peak & 26.1 & \\
\hline 1983 & & & 164 ___-El Paso Mountains & 16.7 & \\
\hline 310 --_Chemehuevi Mountains & 86.5 & -- & $170-\ldots$ - Golden Valley & 29.9 & \\
\hline \multirow[t]{2}{*}{328 ---Coxcomb Mountains } & 57.0 & & 307 -_-_Turtle Mountains & 123.6 & \\
\hline & & & 325 -_-Palen/McCoy & 81.1 & \\
\hline 1984 & & & 341 -Santa Rosa Mountains & 78.4 & \\
\hline 117 --_-Saline Valley & 407.4 & -- - - & 355 -_-_Indian Pass & 30.6 & \\
\hline 117A---Lower Saline Valley & 2.3 & & 355A__-Picacho Peak & 5.7 & \\
\hline 119 --_Little Sand Spring & 40.6 & - - & & & \\
\hline 123 - Hunter Mountain & 20.5 & & 1986 & & \\
\hline 127 - Panamint Dunes & 94.5 & & 143 -_-_Funeral Mountains & 24.8 & \\
\hline 134 -__Wildrose Canyon & 14.4 & & 148 - Greenwater Valley & 55.0 & \\
\hline 142 -_-_Slate Range & 44.9 & & 206 -_-Newberry Mountains & 28.0 & \\
\hline 156 -_-Owlshead Mountains & 128.8 & & 207 ---Rodman Mountains & 23.8 & \\
\hline 250 --_Kelso Dunes & 52.4 & & 222 - Kingston Range & 38.7 & \\
\hline 262 -_-South Providence & & & 239 -_-Cinder Cones & 44.3 & \\
\hline Mountains & 25.7 & & 256 -_-Bristol/Granite Mountains & 45.1 & \\
\hline 334 --_-Eagle Mountains & 55.3 & & 263 -_-Providence Mountains & 63.3 & \\
\hline 344 --_-Orocopia Mountains & 41.2 & & 266 - - - Castle Peaks & 45.0 & \\
\hline 348 -_-Chuckwalla Mountains & 62.3 & & 267 -_-_Fort Piute & 36.5 & \\
\hline \multirow[t]{3}{*}{360 -_-_North Algodones Dunes } & 23.0 & & $343-\ldots-$ Mecca Hills & 8.7 & \\
\hline & & & 368 _-_Jacumba & 28.4 & \\
\hline & & & 372 --_-Fish Creek Mountains & 16.9 & \\
\hline
\end{tabular}

Total CDCA Acreage Under Study--_--_-_---_ 2,594.3

\footnotetext{
${ }^{a}$ Corresponds to the wilderness study area No., "CDCA-000."

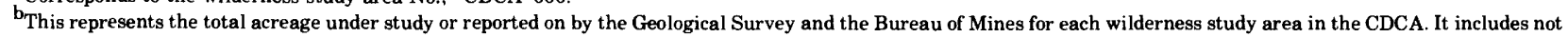

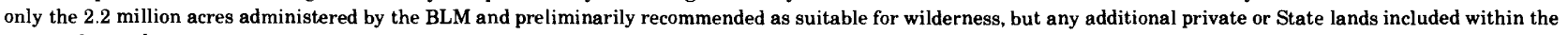
area under study.

${ }^{c}$ U.S. Geological Survey miscellaneous field investigatıons map.

$d_{\text {U.S. Geological Survey open-file report. }}$
}

\section{CALIFORNIA desert Conservation AREA}

A special priority for study was also given in FLPMA to the California Desert Conservation Area (CDCA), which is covered separately by section 601. Because of their unique character and fragile environment, the desert lands required immediate planning and management attention. Of the 25 million acres in the desert region, the BLM manages half. The comprehensive, longrange management plan called for in section 601 was completed and submitted to Congress on Sep- tember 30, 1980. As part of the comprehensive desert plan, BLM identified 5.7 million acres in 138 areas that met its criteria for wilderness. Of these, 2.2 million acres in 47 areas were foundthrough a multiple-use planning process-to be suitable for wilderness and thus to require mineral surveys by the Geological Survey and the Bureau of Mines (fig. 2). In 1983, BLM is amending its original comprehensive plan for the California Desert; in the amended plan some suitable areas may be dropped from wilderness consideration and others added. 
INTENSIVE INVENTORY

174 million acres

151 million acres lack

wilderness characteristics

23.2 million acres of wilderness study areas

Figure 3.-Results of inventory phase of BLM wilderness review.

\section{BLM WILDERNESS INVENTORY}

The BLM published a "Wilderness Inventory Handbook" in September 1978 in which it outlined policy, direction, and procedures for its wilderness inventory. The wilderness review consists of three phases: an inventory phase, a study phase, and a reporting phase.

\section{INVENTORY PHASE}

The inventory phase was divided into an initial inventory, which used existing data to identify land that lacked wilderness characteristics, and an intensive inventory, which focused on lands for which field work was needed in order to conclude whether they had wilderness characteristics. The initial inventory covered the entire 470 million acres administered by the BLM; 296 million acres clearly lacked wilderness characteristics and were dropped from further consideration (fig. 3).

The intensive inventory of the remaining 174 million acres was completed in November 1980. As a result, another 150 million acres were dropped from wilderness consideration, and 23.2 million acres consisting of 928 areas possessing wilderness characteristics as defined by section $2(\mathrm{c})$ of the Wilderness Act were identified and considered as wilderness study areas.

\section{STUDY PHASE}

The BLM recognizes wilderness as a resource deserving consideration with other resources in land use planning, and it recognizes wilderness useage as use to be considered in the framework of multiple-use of public lands. The BLM will recommend for wilderness designation those wilderness study areas for which they determine through their planning process (into which public opinion is incorporated) that wilderness is the most appro- priate use of the land and the resources associated with land.

Federal land management agencies have been and are being required to consider huge acreages for wilderness. This requirement has necessitated the development of a data-gathering process that includes minerals data so that all potential uses of the many tracts under consideration may be evaluated. The Roadless Area Review and Evaluation (RARE II) process met this need for the Forest Service, and the BLM has developed the Geology, Energy, and Minerals (GEM) process to collect minerals data. Such data are part of the information on which suitability/nonsuitability recommendations are based (fig. 4).

BLM's wilderness review guidelines assure that any recommendations related to an area's suitability for wilderness will reflect thorough consideration of any identified resources as well as mineral resource potential. The GEM process, which includes a literature search and collection of available information to develop a data base for each wilderness study area, and an analysis of known mineral resources of the area based on this data, was initiated in 1981 and implemented in 1982. The GEM studies may include limited field verification, but they are not field-oriented. They are designed primarily to use existing data adequate for assessment of resource potential, in contrast to the joint mineral surveys on the suitable wilderness study areas by the Geological Survey and Bureau of Mines required by section 603 of FLPMA. The results of the Geological Survey/ Bureau of Mines mineral surveys are considered by the Secretary of the Interior prior to making his final wilderness recommendations to the President. The information contained in the mineral potential reports may change an area previously recommended as suitable to a nonsuitable recommendation. 


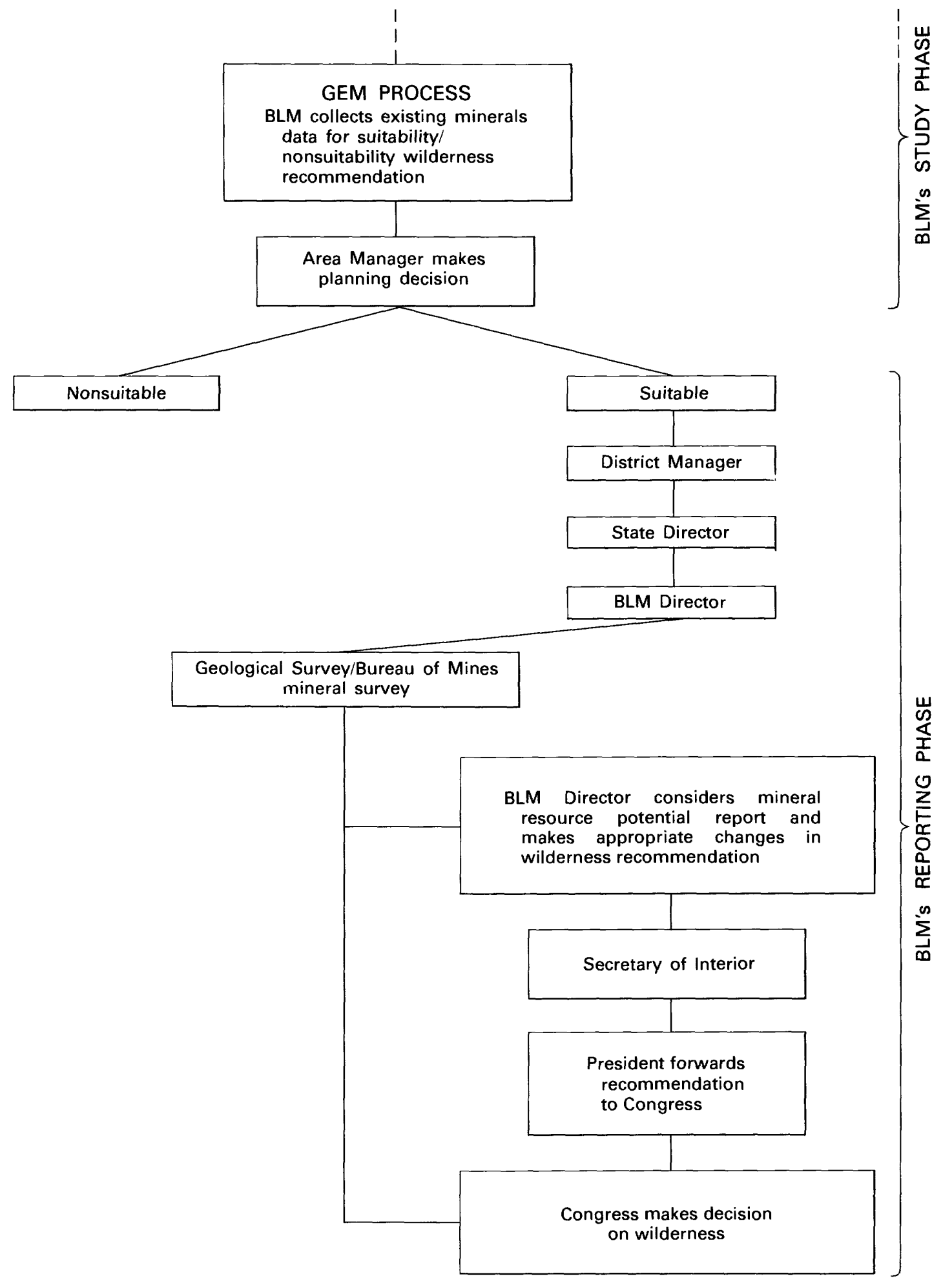

FIGURE 4.-Diagram showing the BLM study phase for wilderness review, which includes their GEM process, and the reporting phase, which includes joint Geological Survey/Bureau of Mines mineral resource potential reports. 


\section{REPORTING PHASE}

In the reporting phase of the wilderness review, suitability recommendations, together with environmental statements, Geological Survey/Bureau of Mines mineral resource potential reports, and other data, are sent to the President who submits them to Congress. The reporting process for "suitable" recommendations-the only areas required by law to have mineral surveys-is shown in figure 4.

\section{MINERAL SURVEYS}

Because virtually all the obvious mineral deposits have been identified, the search for new resources requires current technology combined with a highly sophisticated and thorough knowledge of geologic science. Mineral discoveries such as the gold at Sutter's Mill and the oil of Spindletop occurred at a time when our mineral wealth was much easier to find.

Mineral deposits form by numerous geologic processes and in almost any geologic environment, but unique factors are required to concentrate minerals sufficiently to form a mineral deposit. These deposits are distributed unevenly in the crust of the Earth. Mineral exploration and also mineral resource appraisals may involve many considerations, some of which are listed below:

- The existence of most economic mineral deposits depends upon a complex sequence of geologic conditions and processes. For example, a producibre oil deposit results from sedimentary rocks rich in organic matter; high enough heat to convert the organic matter to oil; a geologic structure or formation that enables the oil to migrate from the source rock to a porous reservoir rock; and a rock that seals the reservoir and holds the oil in place so that it accumulates in quantity.

- Extractable mineral deposits of both fuel and nonfuel minerals occur in localized areas within broad mineralized regions such as the Colorado Mineral Belt, the Viburnum Trend in Missouri, the Coeur d'Alene District in Idaho, or the San Juan Basin.

- As new technologies and new geologic concepts are developed on how mineral deposits form, areas previously poorly explored or unexplored must be reevaluated. For example, the deeper parts of the Rocky Mountain Overthrust Belt had largely been forgotten until 1975 when discovery of the Pineview Field touched off a drilling boom and led to the discovery of billions of barrels of oil and trillions of cubic feet of natural gas.

- New technologies can make previously unimportant minerals highly valuable; examples include uranium, natural gas, tantalum, and lithium.

Wilderness legislation requires mineral surveys in order to provide a basis for making balanced judgments regarding mineral resources and wilderness resources. The Geological Survey and the Bureau of Mines were given the responsibility of conducting wilderness mineral surveys for the following reasons: (1) all facets of mineral resources work are within the joint responsibility of these two agencies; (2) their thoroughness and objectivity has been established and is accepted by those involved in the wilderness recommendation process; and (3) both agencies already possess the extensive technical expertise required to conduct such surveys.

The level of data collected in the course of these mineral surveys is a compromise between cost and time and the amount of detail. This compromise is acceptable to many individuals and organizations interested in the wilderness recommendation process, although the minerals industry would like more detailed surveys. More detailed studies would require costly physical exploration normally undertaken by the private sector, and less detailed studies would not be thorough enough to provide the level of detail needed by BLM and other agencies in determining whether an area should or should not be recommended for wilderness.

The distinction between work done by the Geological Survey and that done by the Bureau of Mines as part of the joint mineral surveys is that the studies of the Geological Survey cover the entire area and are designed to provide a reasonable scientific basis for estimating the possibilities of future mineral discoveries, whereas those of the Bureau of Mines are more site specific and are primarily concerned with the evaluation of individual mines and known mineralized areas. The Geological Survey studies are oriented toward determining geologic units and structures, possible environments of mineral deposition, and presence of geochemical and geophysical anomalies. 


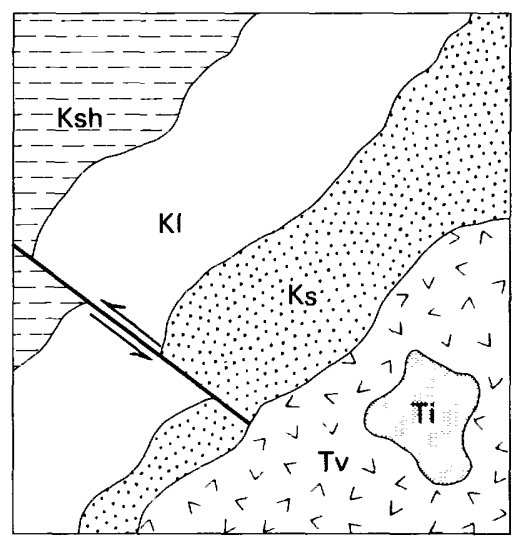

A

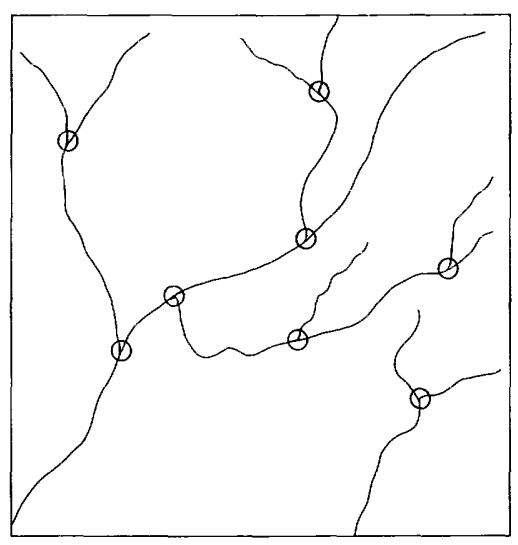

$B$

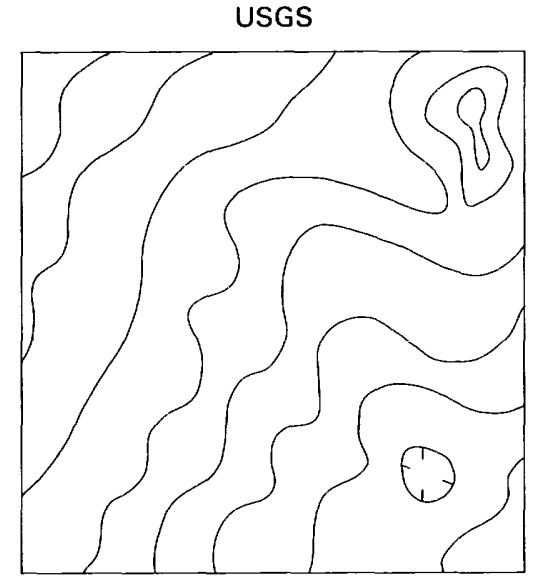

C
USBM

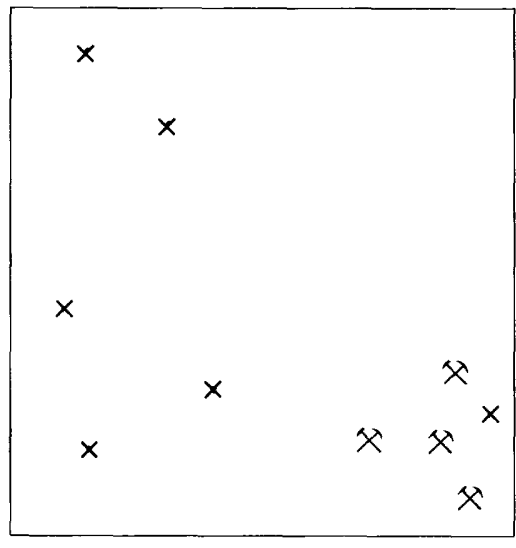

$D$
USGS/USBM

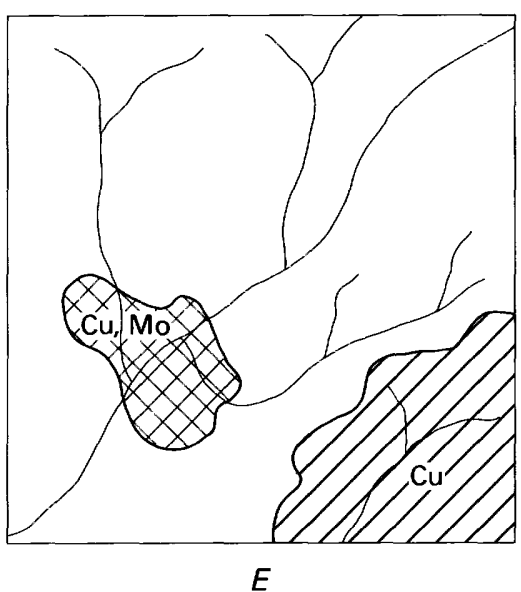

FigURE 5.-Diagrammatic geologic $(A)$, geochemical sample $(B)$, geophysical $(C)$, mines and prospects $(D)$, and mineral resource potential $(E)$ maps. Maps $A$ through $D$ are compiled from various data sources or through field surveys. Map $E$ is an interpretive product.

The Bureau of Mines collects data on current and past mining activities and makes field examinations of mines, prospects, and mineralized areas. In summary, the Geological Survey has primary responsibility for gathering and interpreting data in order to predict the potential for undiscovered resources, and the Bureau of Mines responsibility is to make clear the significance of reserves. Together, the studies of the Geological Survey and the Bureau of Mines attempt to find characteristics present in those wilderness study areas considered as suitable that match characteristics of areas with known mineral deposits. This matching of characteristics is the basis for the evaluation of mineral resource potential. Much of the data from these studies is presented in map form (see fig. $5 A-5 D$ ). The mineral resource potential map (fig. $5 E$ ) is an interpretive product derived from these data.

Although the near-term goal of the Geological Survey and the Bureau of Mines in conducting these mineral surveys is to provide data for land use decisions, their long-term goals are to provide data for strategic planning for our domestic mineral resource base and to add to scientific knowledge and improve the understanding of geologic environments favorable for resource occurrence. Mineral surveys of all wilderness study areas, including those that are evaluated as having little or no potential, have intrinsic value because 
they contribute information on geology that will be useful as resource needs of the United States change. As technology presents new demands and new opportunities, resource appraisals of some areas will need to be updated and conclusions reevaluated.

\section{oeological suRVEy studies}

The Geological Survey uses studies in three separate earth science disciplines-geology, geochemistry, and geophysics-to evaluate the mineral potential of wilderness study areas. The amount of involvement of each of these disciplines is designed to fit the specific needs for data in each wilderness study area or group of closely spaced areas.

The Geological Survey for many years has been conducting mineral resource appraisals for different purposes and at different scales, and its methods are constantly evolving. A workshop, organized for the purpose of improving mineral resource appraisal techniques, was held in Denver, Colorado, in December 1979. Daniel R. Shawe compiled the results in Geological Survey Circular 845, "U.S. Geological Survey Workshop on Nonfuel Mineral Resource Appraisal of Wilderness and CUSMAP1 Areas," published in 1981; the conclusions reached in the workshop are summarized on page 13 of that report:

"...mineral-resource appraisals of CUSMAP quadrangles and wilderness areas should be undertaken in the following steps: (1) compile available data; (2) model possible ore-deposit types; (3) prepare a first-stage analysis of the available data; (4) gather additional needed data through field studies; (5) prepare a final-stage analysis; and (6) present the data in the form of two products, the first an executive summary that is a simple and succinct statement of the results of the mineral-resource appraisal for the use of nongeologists in other government agencies, in the U.S. Congress, and in organizations outside the government who have need of such information, and the second a technical product consisting of data maps and interpretive maps supported by appropriate texts and tables."

In Circular 845, Shawe also includes a comprehensive description of the methodology used by the Geological Survey in mineral resource appraisals, including specific application of each of the three disciplines, which are only briefly described here. The results of these studies are integrated and used to understand past and present geologic

'CUSMAP is an acronym for Conterminous United States Mineral Assessment Program. environments, surface and subsurface geology, processes acting in the area that might produce resources, and to find mineralized systems.

\section{GEOLOOIC STUDIES}

Geologic maps, which show the distribution, age, and relationships of rock units as they crop out at the surface, provide the foundation required for interpretation of all other data collected for mineral assessment (fig. 5). Regional geologic maps produced in other programs portray regional features, including the presence of rocks that may provide an environment for mineral deposits, major structures, and trends associated with mineral deposits. They show the location of structures, including folds, faults, and fractures, that may be factors in localizing processes of mineralization. Examination of the terrane for direct evidence of mineralization, such as presence of ore minerals and altered rock, is an integral part of geologic mapping. Geologic maps enable us to trace geologic evolution in time and space and to define a sequence of geologic environments. They provide a basis for the interpretation of geochemical and geophysical data and enable prediction of mineral resource potential.

A map scale of 1:62,500 ( 1 inch =1 mile), 1:24,000 ( 1 inch $=2,000$ feet), or a scale intermediate between these two depending on the geologic complexity of the individual area, is used in order to show adequate detail (fig. 6).

Greatly improved means of data collection and improved laboratory techniques for analyzing field data, such as isotopic age determinations to provide time frames for volcanic and plutonic rocks and mineralized systems, have enhanced the application of geologic mapping in mineral resource evaluation. Geologic maps display data in an organized fashion. The kinds of features that are now known to be related to mineralization and that we can discern from geologic maps have increased dramatically. Included among these features are ophiolites, calderas and ring fracture zones, and hot spring systems with disseminated gold and silver.

\section{GEOCHEMICAL STUDIES}

Exploration geochemistry is the systematic collection of samples and the measurement of their elemental composition to identify clues to geologic 


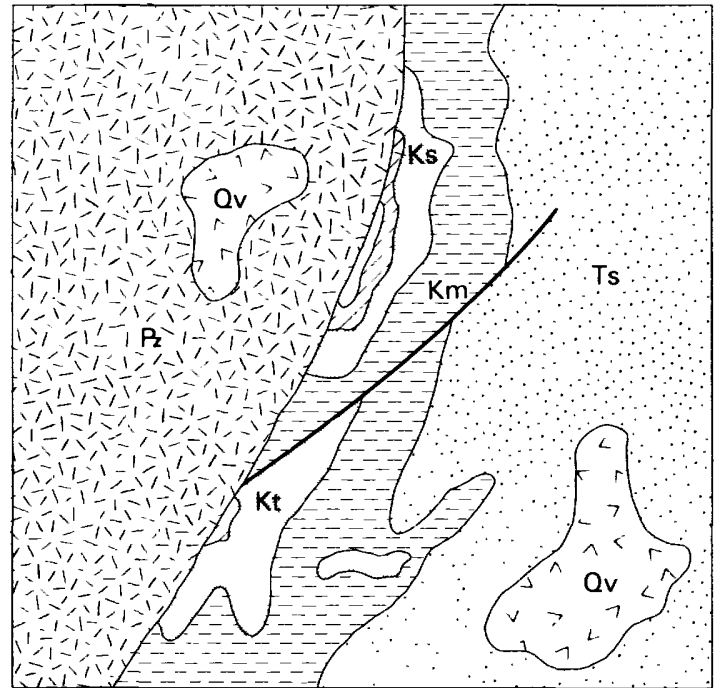

$1: 24,000$

$1^{\prime \prime}=2000^{\prime}$

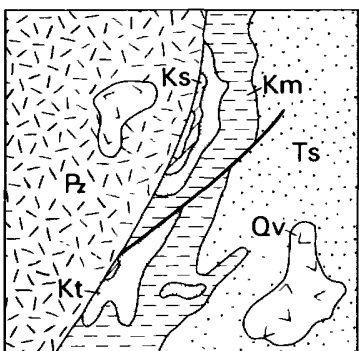

$1: 48,000$

$1^{\prime \prime}=4000^{\prime}$

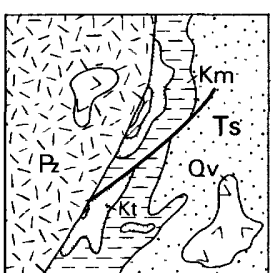

$1: 62,500$

$1^{\prime \prime}=1$ mile

(approximate)

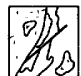

$1: 250,000$

$1^{\prime \prime}=4$ miles

(approximate)

Figure 6.-A geologic map at different scales.

environments that may be favorable for the occurrence of mineral deposits. Analytical geochemical techniques directly measure abundance of elements which, if found in anomalous concentrations (greater than normal throughout the region), may indicate the proximity of a mineral deposit or ore buried at depth. Geochemical studies, combined with geologic mapping and geophysical surveys as an integrated program, have become increasingly important in mineral resource appraisals since the late 1940's.

Virtually all exposed ore deposits were discovered long ago by prospectors; any remaining exposed and most near-surface ore deposits have been discovered more recently by geologists using geologic mapping techniques and drilling. Consequently, emphasis had to shift from the search for exposed mineral deposits to the search for evidence, such as geochemical anomalies, that indicates the possible presence of environments favorable for mineral deposits. With this change in emphasis, geochemistry has become increasingly important. Current resource appraisal must also be directed to studying the potential for mineral commodities not considered in earlier days, such as barite, lithium, and rare-earth elements, and geochemistry is an invaluable aid in detecting these elements.
The geochemical techniques used by the Geological Survey have evolved over more than 30 years. Because of the increased effectiveness of geochemistry in mineral appraisal in recent years, its usefulness in the BLM wilderness program, which is just getting underway, is greater than it was in the first decade of the Forest Service program. The costs that result from extensive use of geochemistry are warranted because of its effectiveness in ferreting out favorable environments for ore deposits that might otherwise be overlooked.

In a reconnaissance geochemical study, one stream sediment sample site per square mile is visited. Two samples are collected at each stream site-one for analysis of the sediment and one for panning to concentrate the heavy minerals. Rock samples are also collected to determine the normal background concentrations of elements in the local bedrock and to serve as examples of atypical material related to mineralization. Water samples are collected from any springs or seeps present in the map area because they may carry elements dissolved from concealed mineralized rocks. Other sample media used in geochemical studies include soils, oxide-coatings, vegetation, and soil gases. A variety of sample media are used to find signs of mineralization that might be 
missed if only one medium were used. An area found to have anomalously high concentrations of elements will be revisited and sampled in greater detail.

Strict quality control is maintained by the Geological Survey in sample preparation and analysis of geochemical samples. All stream sediments, heavy-mineral concentrates, and rock samples are analyzed for 31 elements by the six-step semiquantitative emission-spectrographic technique, and any other more sophisticated unique analysis that is required. Mobile laboratories are taken to some field locations to enable prompt detailed follow-up work in areas showing anomalous concentrations of elements.

The first step in interpretation is preparation of the geochemical anomaly maps, element by element, and the second step is determining whether or not a pattern of anomalous elements is related to mineralization. In order to determine if geochemical anomalies are significant with respect to concealed deposits, several factors must be evaluated including the geology of the area, trace element abundances in the normal rock types of the area, elemental associations in the various types of mineral deposits, climatic conditions, character of weathering, mobility of the elements in the surface and near-surface environments, characteristics of the sample media used, sampling methods, and analytical methods used to obtain the data. The geologic setting of the area, including the rock types, weathering, and structural geology is especially important in evaluating geochemical anomalies as signs of mineralization. Significant geochemical anomalies are related to accumulations of minerals, which may constitute either economic or subeconomic deposits at present. Nonsignificant anomalies may be related to industrial contamination such as old mine tailings or to high-background source rocks.

\section{GEOPHYSICAL SURVEYS}

Airborne geophysical techniques such as magnetic surveys and remote-sensing are extremely useful in mineral resource appraisals because they can be used to detect differences or contrasts in the Earth's crust that are not detectable by direct observation of the Earth's surface. Geophysical methods also allow geologists to ascertain the shape of rock bodies beneath the
Earth's surface. Geophysical surveys can help pinpoint certain areas with abnormal properties that may be related to mineral deposits.

Because in mineral surveys of BLM wilderness areas the areas to be studies are defined, geophysics is used selectively-the technique judged to provide the most useful data is applied. The most commonly used geophysical method is an aeromagnetic survey. Aeromagnetic data provide information about buried intrusive rocks and altered zones that may be associated with mineralization. Aeromagnetic surveys can be done rapidly and at a relatively low cost. As in geochemical studies, anomalous areas, in this case areas with abnormal magnetic properties, may be followed with a detailed ground survey.

A second geophysical reconnaissance technique, one that is most useful in semiarid and arid terranes, is a remote-sensing technique using Landsat data to detect and map limonite (iron oxides). The limonite maps are field chec'sed to determine whether or not the limonite results from weathering of hydrothermally altered rocks. The resulting hydrothermal alteration maps, combined with geochemical data, help locate buried mineralization. This remote-sensing approach has been used effectively in the mineral surveys of the California Desert Conservation Area.

Other geophysical methods include gravity surveys (density of rocks) and electrical profiling (electrical properties of rocks), including magnetotellurics and DC electrical resistivity. Reconnaissance methods provide maps of different physical properties that augment geological surface mapping; such maps are most useful when they include data on several different physical properties.

Site-specific geophysical methods include gravity and magnetics as well as induced polarization (IP), electromagnetic, radiometric, and selfpotential methods. The electrical and radiometric methods are used in some cases as direct indicators of mineralization. These methods are used very selectively in mineral surveys of wilderness study areas because they are expensive.

\section{BUREAU OF MINES STUDIES}

Bureau of Mines studies of wilderness study areas involve collection of data on current and past mining activities and field examination of mines and 
prospects. The Bureau's work is accomplished in three investigative phases. During the first, or "pre-field" phase, all existing information on the area is located and researched. Data relating to current and past mining activities within and near the study areas are obtained from a variety of sources. BLM mining claims records are consulted in order to locate patented and unpatented claims, and BLM's mineral lease records are searched for evidence of any past activity in the area. County courthouse records are used to establish the ownership of patented claims, the identity of claimants of unpatented claims, and locations of all claims.

Past production figures are obtained from Bureau of Mines records, from Bureau of Land Management lease records, and from State or other agencies that might have production records. Aerial photographs are obtained and studied to identify areas of interest around known mines or mineral occurrences for future on-theground examination. Mine operators, claimants, and local property holders are then contacted for any additional information they might have, and written permission to examine their properties and publish the results is obtained.

The second, or "field" phase, consists of one or more visits to the study area. During field examinations, all abandoned mine workings and dumps, prospects, and known mineral occurrences are examined to assess the mineral supply potential of recognized productive or geologically favorable sites. During the investigation, claims within or near the study area, all State and Federal mineral leases, and any exposed coal, metallic, or nonmetallic deposits are visited and sampled. Accessible mine workings are surveyed and systematically chip sampled. Inaccessible workings are sampled at the surface and dump material is sampled, analyzed, and evaluated. Pan samples are collected at selected sites, particularly downstream from zones of alteration, and placers are sampled from bankcuts wherever possible. If the area is near enough to markets so that materials of low bulk value could be economic, potential sand and gravel deposits are visited and evaluated.

Samples of mineralized rock are analyzed to determine metal values. Samples are fire assayed for gold and silver and spectrographically analyzed for other elements. Special analyses are completed when spectrographic results indicate a need for additional data. In some instances, anomalous results may require additional sampling or a reinvestigation of an area. The analytical determinations are done either in Bureau of Mines laboratories or through contracts with industrial laboratories.

The final phase of the investigation involves the interpretation of the data collected and the preparation of a report. To expedite release to the public, the Bureau of Mines compiles the results of its work into a Mineral Land Assessment (MLA) open-file report for immediate release. Reports typically include information on mining claims, past and present mining activity, past and present production, and reserve estimates where obtainable.

\section{MINERAL RESOURCE POTENTIAL REPORT}

Mineral resource potential reports, a major element of which are maps (fig. 7), are created to show variations in potential within individual areas. The production of such reports requires knowledge of mineral occurrence and mineral occurrence models as well as the ability to make subjective evaluations of mineral resource potential. The Geological Survey and the Bureau of Mines collectively possess the technical expertise and the experience necessary in solving the particular earth-science problems related to mineral assessment of public lands.

The mineral resource potential of an area can be arrived at only by integrating many diverse factors, some of which can be measured and some of which are subjective and depend in part on the specific experience and the knowledge of the individual making the assessment. The single most important factor in all mineral appraisals is the judgment of the scientists who integrate a wide range of geologic elements. Lacking direct evidence from drilling, favorable ground is defined largely by comparing available data with models of known ore deposits. In evaluating geologic environments favorable for ore deposits, many factors must be considered including host rock type, structures present, evidence of mineralization, geochemical anomalies, and geophysical anomalies.

A method of mineral exploration commonly used by the mining industry consists of developing a conceptual mineral deposit occurrence 


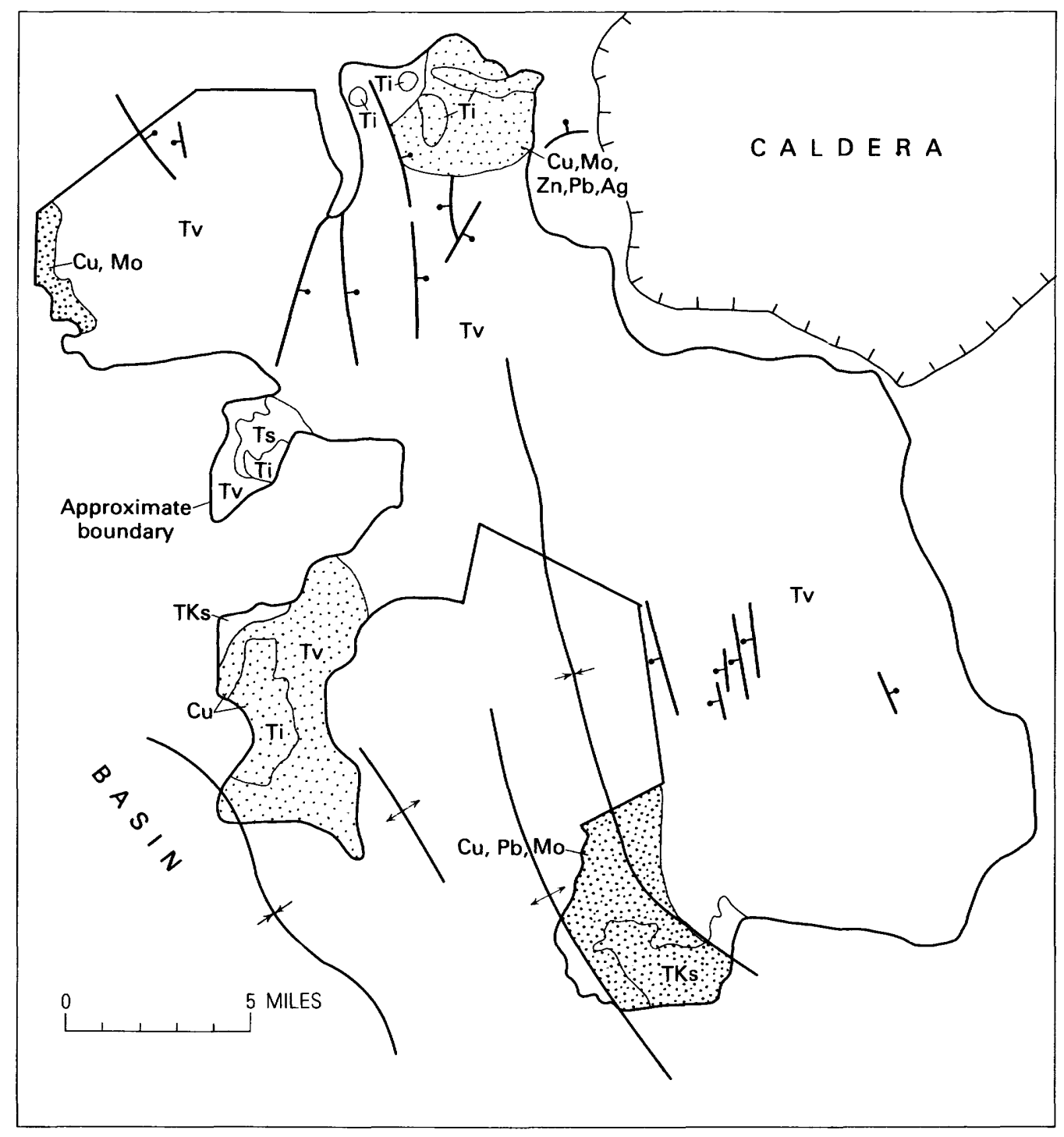

\section{EXPLANATION}

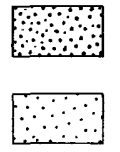

Geologic terrane with high mineral-resource potential

Geologic terrane with moderate mineral-resource potential

$\begin{array}{ll}\mathrm{Cu} & \text { Copper } \\ \mathrm{Pb} & \text { Lead } \\ \mathrm{Mo} & \text { Molybdenum } \\ \mathrm{Ag} & \text { Silver } \\ \mathrm{Zn} & \text { Zinc }\end{array}$

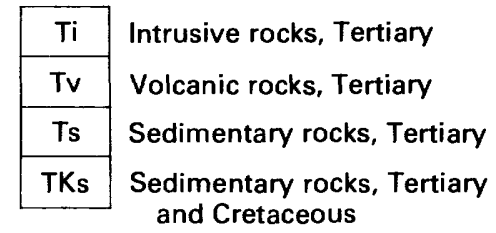

- Contact

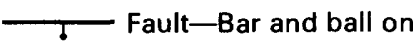
downthrown side

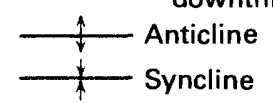

Figure 7.-Mineral resource potential map. 
Bureau of Mines studies ( 3 years)

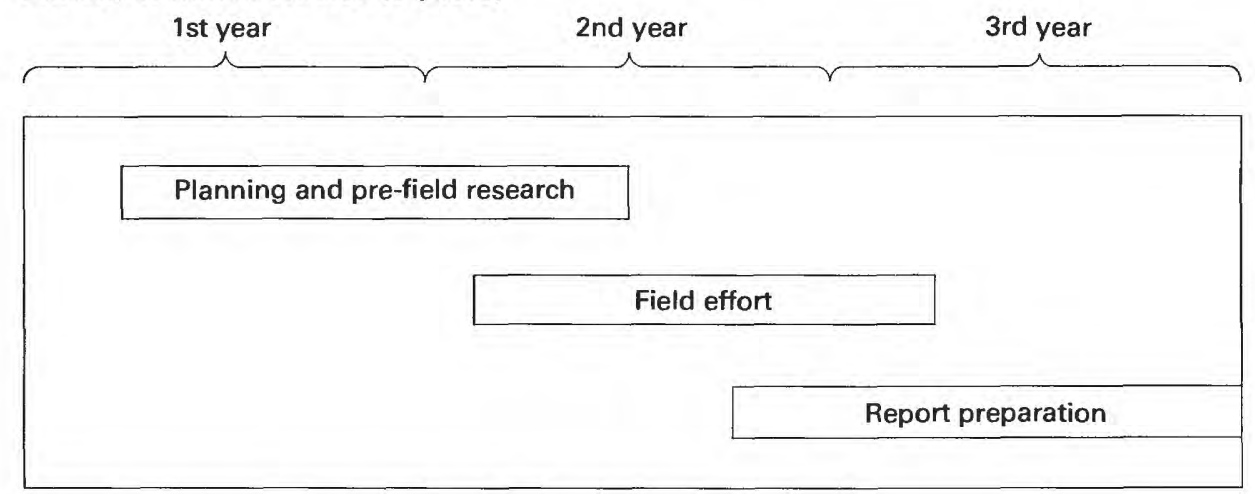

Geological Survey studies (4 years)

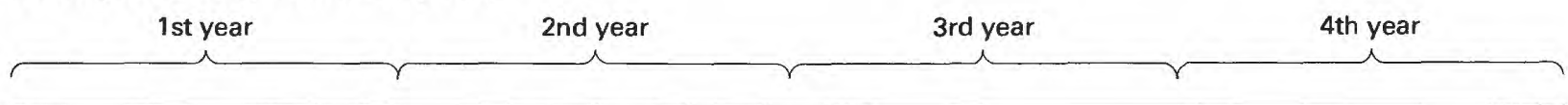

Planning and

pre-field research

Field effort

Report preparation and publication

Figure 8.-Steps involved in and time required for mineral surveys by the Geological Survey and the Bureau of Mines.

model-a set of characteristics that describe the environment of a particular type of deposit-and then using the model to select areas to be explored. This approach is still in the development stage, and its use is limited by the fact that models for many types of mineral deposits are as yet only partially defined, especially in regard to their geochemical and geophysical characteristics. In mineral surveys on BLM wilderness study areas, however, the steps outlined above are reversed: the target area (wilderness study area) has already been defined by the BLM and now must be studied to see if it contains geologic, geochemical, and geophysical characteristics that might suggest mineral occurrences or reflect known mineral deposit types. Even though the effective use of models in this context is also limited, the search, through multidisciplinary studies, for characteristics that may indicate the presence of mineral deposits is the best approach available and is the one used by the Geological Survey and Bureau of Mines in assessing mineral resource potential.

To arrive at a mineral resource potential assessment of a BLM wilderness study area, the data gathered by the Geological Survey as a result of geologic, geochemical, and geophysical studies are integrated and then combined with information on mines, prospects, and mineralized areas gathered by the Bureau of Mines. These newly acquired data, when added to the historical information already in the literature and interpreted relative to modern ore deposit models, result in an authoritative mineral resource potential assessment. The Geological Survey study requires an average of 4 years to complete and the Bureau of Mines requires an average of 3 years (fig. 8). The resulting mineral potential report is published jointly by the two agencies. 
Categories of BLM wilderness study areas

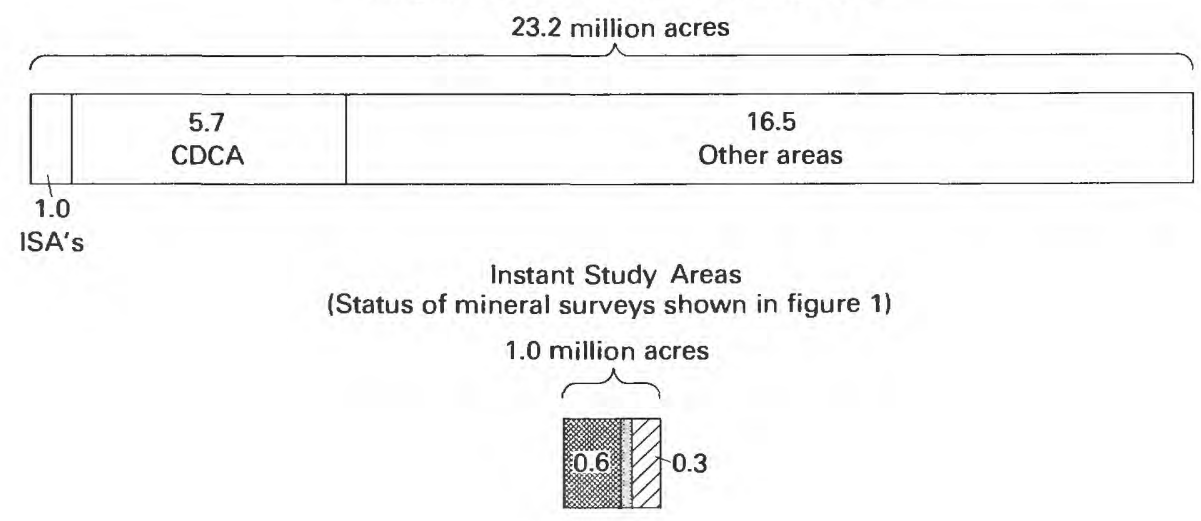

\section{California Desert Conservation Area}

(Status of mineral surveys shown in figure 2)
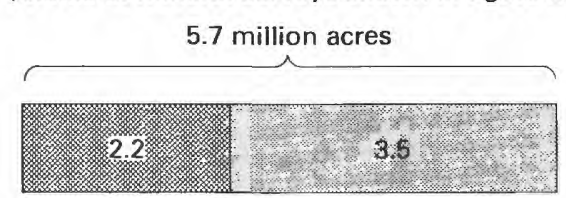

Other areas

16.5 million acres

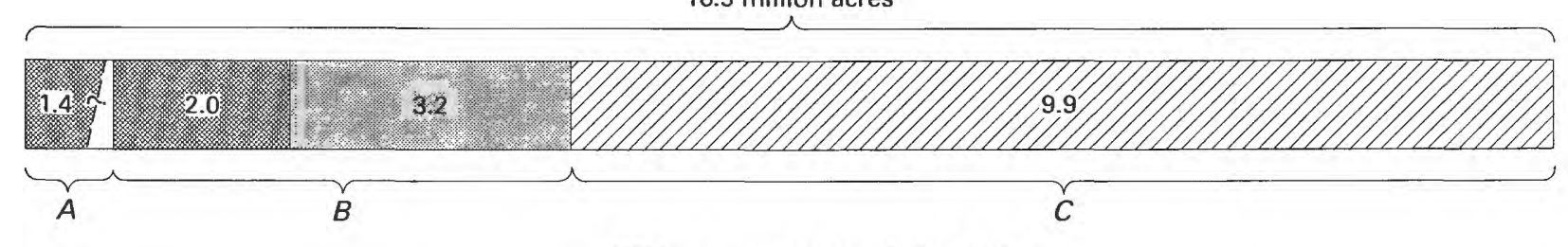

Wilderness recommendation status

Suitable Unsuitable DID Recommendation not yet made

Figure 9.-Status of mineral surveys of Instant Study Areas, the California Desert Conservation Area, and other areas in the BLM wilderness program as of May 1983. 


\section{STATUS OF THE INTERIOR DEPARTMENT'S WILDERNESS PROQRAM}

Of the 23.2 million acres of BLM wilderness study areas, 1.0 million acres are Instant Study Areas, 5.7 million acres are in the CDCA, and 16.5 million acres are other areas. The status of mineral surveys of these different categories of wilderness study areas is shown in figure 9.

\section{NATURAL AND PRIMITIVE AREAS (INSTANT STUDY AREAS)}

Mineral surveys have been completed on all suitable ISA's. No changes were necessary in the suitability recommendations as a result of the mineral surveys because the areas were not found to have significant mineral potential. Mineral surveys have also been completed in 10 of the deferred-study ISA's. Less than 0.4 million acres of ISA's remain under consideration for wilderness (fig. 1).

\section{CALIFORNIA DESERT CONSERVATION AREA}

Of the 5.7 million acres of wilderness study areas in the CDCA, 2.2 million acres were recommended for wilderness as part of the 1980 comprehensive desert plan (fig. 2). As of May 1983, mineral resource potential reports have been published on about half a million acres, mineral surveys are in progress on about 1.5 million acres, and surveys will be started on the remaining half a million acres in fiscal year 1984. The schedule for completion of mineral survey reports in the CDCA is shown in figure 2.

\section{Other AREAS}

Wilderness study areas other than ISA's and the CDCA total 16.5 million acres. Of this total, mineral surveys are currently completed or underway on 1.1 million acres (fig. 10). BLM tentatively recommended 2.0 million areas as suitable at the end of fiscal year 1982. The Geological Survey and Bureau of Mines will begin mineral surveys of these areas in fiscal year 1984 .

About 9.9 million acres remains under review by BLM. In January 1983, the Directors of the Geological Survey, the Bureau of Mines, and the Bureau of Land Management signed a Memorandum of Understanding (MOU) concerning the mineral surveys of wilderness study areas. The MOU, shown in Appendix A, covers policy and operational procedures and also includes the schedule by which BLM will complete review of the remaining 9.9 million acres.

On the basis of past experience, it has been assumed for budget and workload purposes that not more than 65 percent of these remaining 9.9 million acres, or about 6.5 million acres, will be recommended as suitable. If this is the case, mineral surveys of the remainder of the program can be completed according to the schedule shown in table 1 and can meet the mandated $1991 \mathrm{com}$ pletion date for the program. In accordance with the Memorandum of Understanding (see appen$\operatorname{dix}$ A), the Bureau of Land Management has, as of May 1983, provided the Geological Survey and Bureau of Mines with the total number of acres (2.3 million) for which mineral surveys are to be started in fiscal year 1985 for use in the budget process.

TABLE 1.-Schedule for completion of remaining acreage of BLM wilderness study areas recommended as suitable ${ }^{1}$ [Figures per year are thousand acres]

\begin{tabular}{lrlllll}
\hline 1985 & 1986 & 1987 & 1988 & 1989 & 1990 \\
\hline 1st year field effort ----2,300 & 2,000 & 2,000 & 200 & --1 & - \\
2nd year field effort ---2,500 & 2,300 & 2,000 & 2,000 & 200 & - \\
Report published $----2,500$ & 2,300 & 2,000 & 2,000 & 200 \\
\hline
\end{tabular}

${ }^{1}$ Assumes that 65 percent of areas under wilderness review ( 9.9 million acres) will be recommended as suitable. 
Wilderness study areas (WSA's) outside the California Desert Conservation Area and currently under study or completed [Reports to be published in year shown on map, facing page]

\begin{tabular}{|c|c|c|c|c|}
\hline Map No. & WSA Number & Wilderness Study Area & $\begin{array}{l}\text { Report/study area }{ }^{1} \text { in } \\
\text { thousands of acres }\end{array}$ & $\begin{array}{c}\text { Geological Survey/Bureau of Mines } \\
\text { report No. }\end{array}$ \\
\hline
\end{tabular}

1980

1

1981

2

1982

3

4

5

1983

6

7

8

9

10

11

1984

12

13

14
NV-050-0414

Pine Creek

30.9

54.4

CA-050-112

King Range

$\begin{array}{rc}7.4 & \text { Paria Plateau (MF-1475D) }^{3} \\ .5 & \text { Do. }^{3} \\ .1 & \text { Do. }^{3} \\ .1 & \text { Do. }^{3} \\ 252.2 & \text { Do. }^{3} \\ 7.3 & \text { Do. }^{3} \\ 17.8 & \text { Gila-San Francisco } \\ 28.4 & (\text { MF-1315-B) } \\ 107.0 & \text { Do. } \\ & \text { Muddy Mountains } \\ & (\text { MF-1458C) }\end{array}$

AZ-040-023/024B--_-_---Turtle Mountain NV-050-0229 _-_-_-_-_-_Muddy Mountains

Red Rocks Escarpment (OF 80-1055)

Chemise Mountain \& King Range (MF-1196C) ${ }^{3}$
12.9

19.5

9.5

33.3

40.1

12.9

7.7

90.0

19.9

6.6

4.0

4.6

Tunnel Ridge
Emmett Wash (OF 82-927)

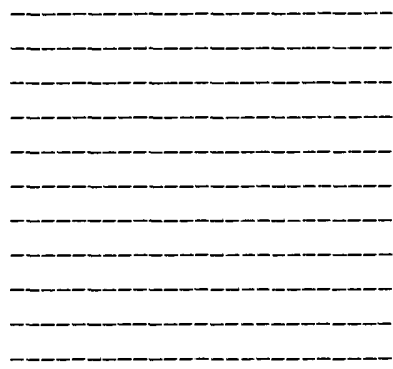

46.2

13.5

4.9

3.2

3.1

.2

.6

61.0

38.8

54.5

27.0

38.7

$1,058.8$

${ }^{1}$ Mineral surveys were started on 1.4 million acres, 300,000 of which have been dropped from wilderness consideration and mineral surveys discontinued. The 1.1 million acres remaining and shown here may include additional acreage that will be later recommended as unsuitable.

'U.S. Geological Survey open-file report.

'U.S. Geological Survey miscellaneous field investigations map. 


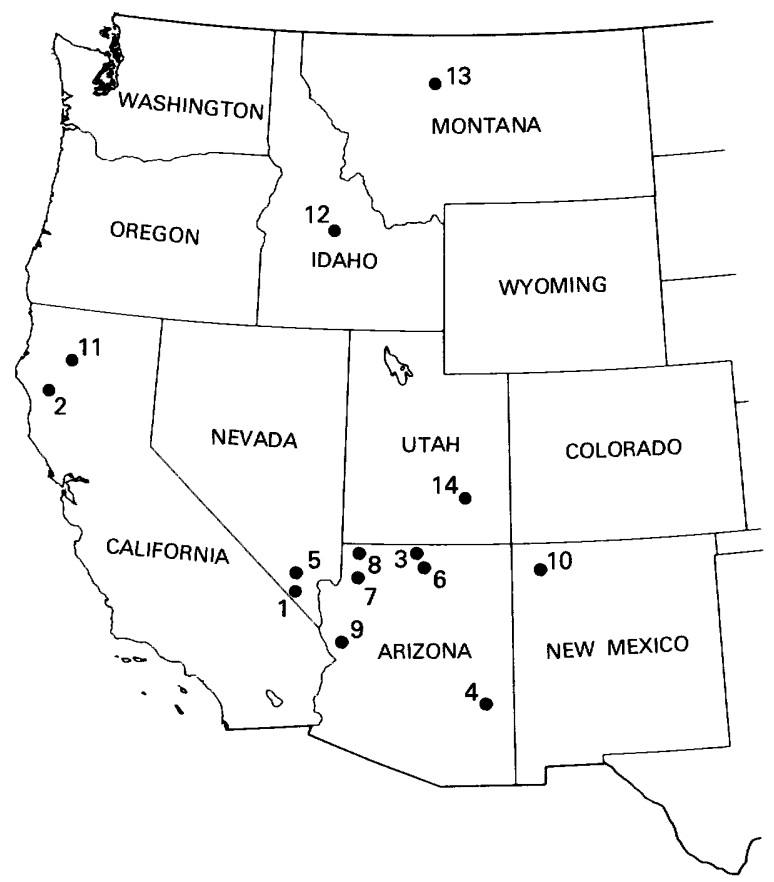

FIGURE 10.-Locations of wilderness study areas outside the California Desert Conservation Area currently under study or completed (above), and schedule for completion of mineral resource potential reports (left). 


\title{
APPENDIX A.
}

\author{
Memorandum of Understanding \\ between \\ the United States Geological Survey, the Bureau of Mines, \\ and the Bureau of Land Management \\ for \\ Mineral Surveys of Wilderness Study Areas
}

I. Policy. It is the policy of the Directors of the U.S. Geological Survey (GS), Bureau of Mines (BM), and Bureau of Land Management (BLM) to effect the letter and spirit of section 603(a) of the Federal Land Policy and Management Act which requires "that prior to any recommendation for the designation of an area as wilderness the Secretary shall cause mineral surveys to be conducted by the Geological Survey and the Bureau of Mines to determine the mineral values, if any, that may be present in such areas."

Further, it is the policy of the Director, BLM that minerals data for wilderness suitability/nonsuitability recommendations will be provided through BLM's GEM assessments. Consultation with GS or BM relating to these assessments, if necessary, will be done through the Task Force at the request of BLM representatives.

II. Purpose. This memorandum of understanding establishes a Mineral

Survey Task Force to coordinate, 1mplement, and monitor the GS/BM

Section 603 mineral survey program of those areas preliminarily

recommended by BLM State Directors as suitable, as reviewed by the appropriate BLM Assistant Directors, for inclusion in the National W11derness Preservation System.

III. Budget. GS and BM will justify direct appropriations starting in FY 1984. For budget justification purposes, by March 15 of each year, BLM will provide GS and BM with the total acreage of areas for which mineral surveys are to be started two years later. For example on March 15, 1983, BLM w111 provide the total acreage for which the mineral surveys will be started by GS and BM in FY 1985. For FY 1984 starts, the BLM w1ll 1dentify approximately two million acres in areas outside the California Desert. 
IV. Operations. The GS, BM, and BLM will follow the guidelines and procedures listed below:

A. The Mineral Survey Task Force will consist of:

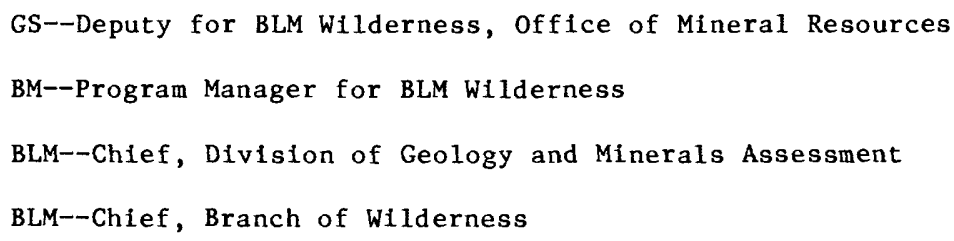

B. The contact at BLM will be the Chief, Division of Geology and Minerals Assessment.

C. The GS will provide the appropriate State Director of BLM with 25 copies of the GS/BM mineral survey report for each of the areas surveyed as soon it is printed and will notify the Task Force members of its transmittal. Additionally, the GS will provide 10 copies to the BLM Director (340), and one copy each to the Task Force members.

D. The following program actions will be implemented:

1. Scheduling

a. The schedule for mineral surveys, by year, is shown in the attached Appendix.

b. The Mineral Survey Task Force will meet by March 15 of each year to develop the final 603 mineral survey schedule for the following fiscal years work. At this meeting, in addition to the information to be provided by BLM as Indicated in section III, the BLM will also provide GS and $B M$ with the following: 
(1) A 11st with the name, number, acreage, and BLM area office contact for each of the WSAs for which the GS and BM will start a mineral survey.

(2) The BLM Task Force members w111 provide one set of maps, showing boundaries of WSAs, to the GS and one set to the BM, at a scale of $1: 62,500$; if ava11able, or otherwise at the most useful scale, at the March 15 meeting or no later than 30 days following the meeting.

(3) Subsequent to the March 15 meeting, any boundary change will be made by the BLM Task Force members In writing to the BM and GS Task Force members. The written notification will include the name and number of the WSA and revised acreage figure and a new map on the same scale as previously supplied outlining the new WSA boundary.

c. Within four weeks of the March 15 meeting, a BLM Task Force representative, will send a memorandum to each approprlate Resource Area Manager, through the State Director, bringing to their attention the impending GS and BM work within their area, and the need to involve their staff with the GS and BM during their field work.

d. The GS and BM w11l provide a list of project leaders with their office address and phone numbers, for each WSA, to the BLM office administering that WSA and to the 
BLM Task Force members by no later than September 15 of each year. The estimated start-up and completion dates of field work will be made a part of this 11 st for each WSA.

2. Program Review and Program Reports

a. At the March 15 meeting and at three other meetings to be held no later than June 15, September 15, December 15, the Task Force will compare Individual status reports. The Task Force will also prepare an annual foint status report concerning BLM's wilderness program and the required GS/BM section 603 mineral surveys. The annual report will be transmitted to the directors of BLM, GS and BM, following the December 15 Task Force meeting.

b. The foint report will track such items as:

- Exchange of lists of project leaders responsible for individual WSAs;

- Progress of mineral surveys; and

- Progress of GEM assessments.

E. After the March 15 annual meeting and prior to starting field work, GS and BM field representatives will contact the respective BLM Resource Area Manager to arrange detalls concerning logistics, radio communications, exchange of data, reports of wildife sighted, and other matters of mutual concern. The GS and BM will specifically ensure the BLM Area Manager that fleld operations will not violate the Interim Management Policy dated December 12, 1979, as amended. 
Project Chief of GS fleld operations will provide the BLM Area Manager with a press release describing the section 603 Mineral Surveys that are to be conducted by GS and BM. The Area Manager can then notify local residents of their purpose by notices in local newspapers and posting on bulletin boards.

GS and BM are responsible for obtaining necessary access across private or State lands; however, BLM Area Managers will provide reasonable assistance in any aspect of the fleld operations.

V. Effective Date. This agreement supersedes the MOU of August 31 , 1981, and will become effective on the date of the last signature, and w111 remain in force unless and unt1l terminated by the Director, GS; or the Director, BM; or the Director, BLM; upon 60 days written notice to all parties. Amendments may be proposed by any party at any time, and will become effective upon joint approval.
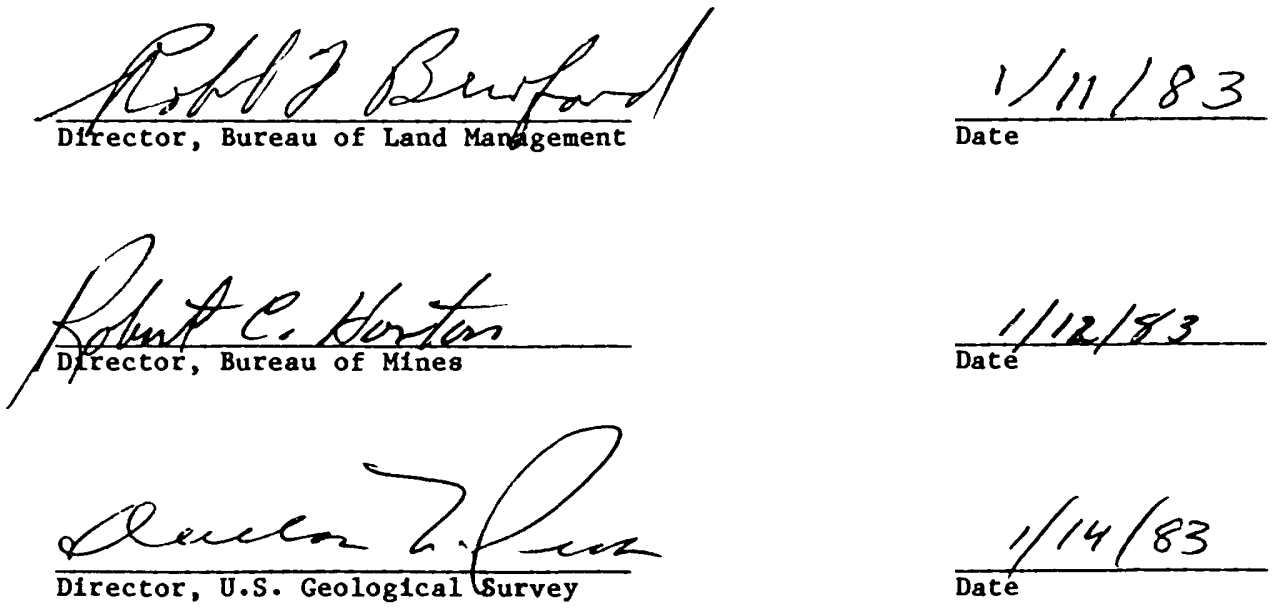


\title{
APPENDIX B. ATTACHMENT TO MOU
}

\begin{abstract}
(Based on BLM plan completion dates as of the Federal Register dated July 8, 1982)
The Appendix contains a schedule of GS/BI1 mineral survey starting dates based on the BLM's scheduled plan/EIS completion dates. The acreage figures in the Appendix represent the total BLM WSA acreage being studied in each planning effort. It is important to point out that these acreage figures do not represent the actual acreage for which mineral surveys will be conducted. Because mineral surveys w111 be undertaken only for BLM WSA's preliminarily reconmended suitable for wilderness designation, the nineral survey acreage will generally be less than the BLM study acreage presented in the Appendix. Annual total acreage will remain essentially the same; however, individual areas are subject to change.
\end{abstract}

\section{FY 1984 Starts}

BLM plan completion by Sept. 30, 1982 (FY 1982)

GS/BN start Section 603 mineral surveys of recommended WSA's on Oct. 1, 1983

Plan Name

CDCA (Al1 remaining acreage)

Clear Lake, CA

E. San Diego County, CA
Taylor-Hilgard, MT

Central California, CA

Western Counties, CA

American Flats, $\mathrm{CO}$

Cannibal Plateau, CO

West Needles, CO

Owyhee, ID

North Idaho, ID

Missouri Breaks, MT

Dillon, MT

Deerlodge, MT

(USFS)

(USFS)

Tonopah, NV

$$
\begin{array}{rr}
\text { Acreage }^{a} & \\
500,000 & \text { (Approx.) } \\
40,765 & \\
54,022 & (40,086) \\
1,469 & \\
89,522 & (14,430) \\
30,954 & \\
78,135 & (22,375) \\
3,480 & \\
5,780 & \\
93,610 & (41,550) \\
38,468 & \\
170,150 & (79,770) \\
94,409 & (26,201) \\
860 & \\
483,800 & (234,080)
\end{array}
$$

Tota1 CDCA Acreage 500,000

Total Acreage Outside CDCA $1,185,424$

\footnotetext{
${ }^{a}$ Acreages in parentheses (added) are those for which preliminary recommendations of suitable for wilderness have been made by BLM and for which Geological Survey/Bureau of Mines mineral surveys start in fiscal year 1984. Total is approximately 2.0 million acres.
} 
BLM plan completion by Sept. 30, 1983 (FY 1983)

GS/BM start Section 603 minera1 surveys of recommended WSA's by Oct. 1, 1984

Plan Name

Upper Sonoran, AZ

Saf ford, AZ

Coronado, AZ

Apache-Sitgreaves, AZ

Los Padres, CA

Sequoia, CA

Inyo, $\mathrm{CA}$

Toi yabe, CA

Tahoe, CA

Stanislaus, CA

Alturas, $\mathrm{CA}$

Lassen, CA

Plumas, CA

Benton-Owens Valley/Bodie Coleville, CA

White River, $\mathrm{CO}$

Kremmling, CO

Cross Mountain, CO

Canyon City, CO

Sangre de Cristo, CO

Glenwood Springs, CO

Big Lost/Mackay, ID

Eastern Idaho, ID

Shoshone/Sun Valley, ID

Billings, MT

Wells, NV

Winnemucca, NV

Sche11, NV

Shoshone/Eureka, NV

Overland/Divide, WY

Rock Springs, WY

Buffalo, WY

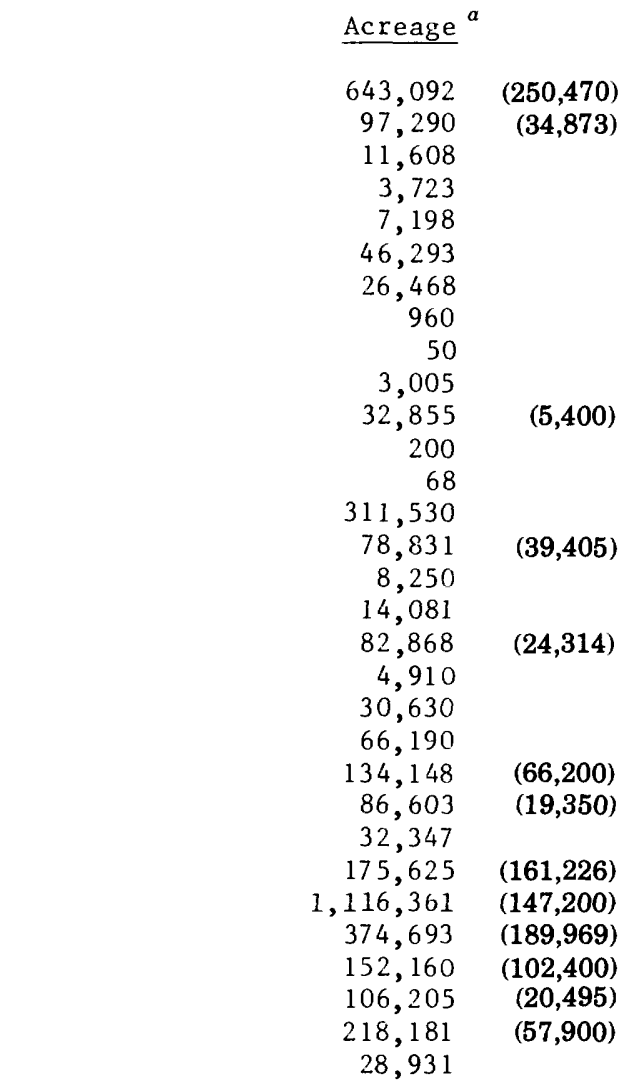

Total Acreage $\quad 3,895,354$

$$
3,895,354
$$

(USFS)

(USFS)

(USFS)

(USFS)

(USFS)

(USFS)

(USFS)

(USFS)

(USFS)

\footnotetext{
${ }^{a}$ Acreages in parentheses (added) are those for which preliminary recommendations of suitable for wilderness have been made by BLM and for which Geological Survey/Bureau of Mines mineral surveys start in fiscal year 1984. Total is approximately 2.0 million acres.
} 
BLM plan completion by Sept. 30, 1984 (FY 1984)

GS/BM start Section 603 mineral' surveys of recommended WSA's by Oct. 1, 1985

Plan Name/Resource Area

Cerbat Black, AZ

Phoenix, AZ

Lower Gila South, AZ

Havasu, AZ

Redding, CA

Mendocino, CA

(USFS)

Eagle Lake/Surprise, CA

King Range/North Coast, CA

San Juan, CO

Owyhee Canyonlands, ID

Jack's Creek, ID

Powder River, MT

Valley, MT

Egan, NV

Caliente, NV

Clark, NV

Rio Puerco, NM

Taos, NM

San Augustine, NM

Jornado, NM

Las Cruces/Lordsburg, NM

White Sands/Jornado, NM

Roswel1, NM

Carlsbad, NM

Carlsbad, NM

(USFS)

High Desert, OR

Warner Lakes, OR

Riley, OR

Warner Lakes/Riley/Andrews, OR

Andrews/Southern Malheur, OR

John Day, OR

Northern Malheur, OR

Central Oregon, OR

Deschutes/0choco, OR

(USFS)

Deschutes/Central Oregon, OR

Baker, OR

Grande Ronde, OR

Klamath, OR

Myrtlewood, OR

Pony Express/House Range, UT

Dixie, UT

Kanab/Escalante, UT

Beaver River, UT

Warm Springs/Beaver River, UT

House Range, UT

San Rafael/Henry Mtns., UT
Acreage $^{a}$

266,571

34,992

637,346

278,740

29,778

33,397

486,605

38,515

90,135

226,523

175,637

15,574

59,112

305,825

605,991

437,935

81,280

30,560

60,166

273,095

354,504

39,537

25,885

2,963

2,941

197,720

139,840

5,560

667,935

${ }^{b} 1,176,260$

10,503

256,100

38,974

3,114

119,835

16,580

2,935

5,960

$(212,175)$

$(248,900)$

133,483

99,222

492,119

7,033

217,588

111,150

222,905

\footnotetext{
${ }^{a}$ Acreages in parentheses (added) are those for which preliminary recommendations of suitable for wilderness have been made by BLM and for which Geological Survey/Bureau of Mines mineral surveys start in fiscal year 1984. Total is approximately 2.0 million acres.

$b_{\mathrm{BLM}}$ has reviewed only 371,650 acres and made preliminary suitability recommendations on 248,900 acres.
} 
Price River/San Rafael/Grand, UT Grand, UT

San Juan, UT

Diamond Mtn., UT

Book Cliffs, UT

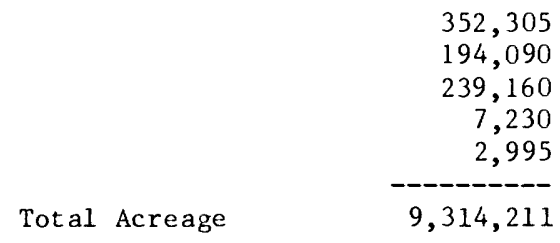

FY 1987 Starts

BLM plan completion by Sept. 30, 1985 (FY 1985)

GS/BM start Section 603 mineral surveys of recommended WSA's by 0ct. 1, 1986

Plan Name

Acreage

Yuma, AZ

83,940

Little Snake, CO

Jarbidge, ID

Medicine Lodge, ID

68,472

Lemhi, ID

Monument, ID

Garnet, MT

Lander, WY

216,708

22,220

24, 922

154,015

27,737

53,496

Total Acreage

651,510

FY 1988 Starts

BLM plan completion by Sept. 30, 1986 (FY 1986)

GS/BM start Section 603 mineral surveys of recommended WSA's by Oct. 1, 1987

Plan Name

Uncompahgre, $\mathrm{CO}$

Grand Junction, CO

Elko, NV

Lahontan, NV

Walker, NV

Esmeralda, NV

Grass Creek, WY

Washakie, WY

Cody, WY

Medicine Bow, WY

Pinedale, WY

Big Sandy, WY
Acreage

48,970

241,005

96,471

424,345

88,835

191,875

52,460

71,040

25,210

16,191

1,415

1,300

Total Acreage

$1,259,117$

(Grand total acreage outside CDCA-_---16, 305,616) 